امكانسنجى كاربرد علف كشهاى رايج برنج نشايى در كشت مستقيم مرطوب رقم هاشمى

وحيده على يور استخرى'، جعفر اصغرى ب"، سيدمحمرضا احتشامى " و الميرا محمدوند"

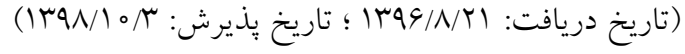

جكيده

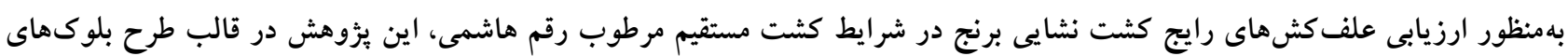

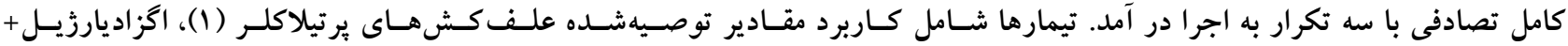

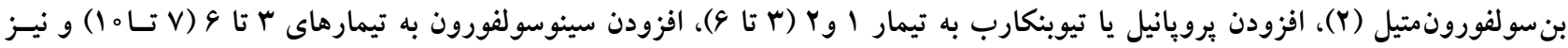

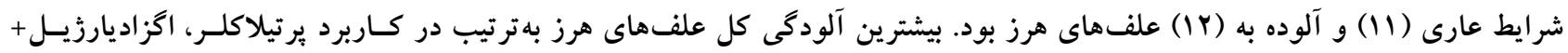

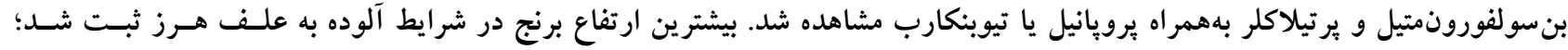

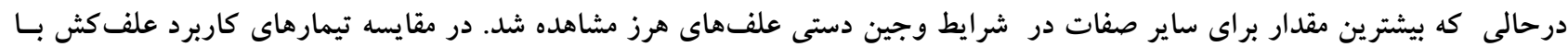

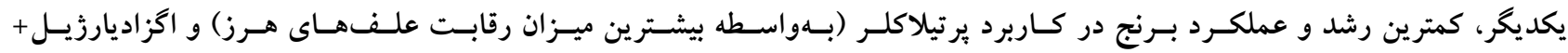

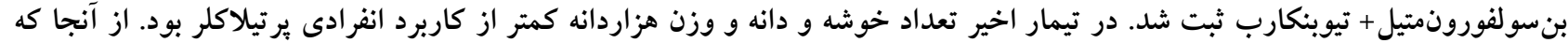

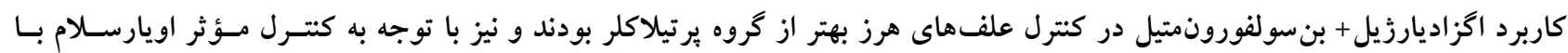

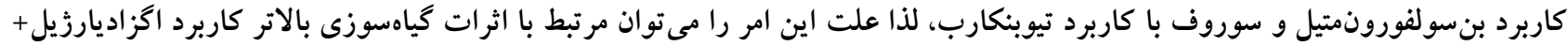

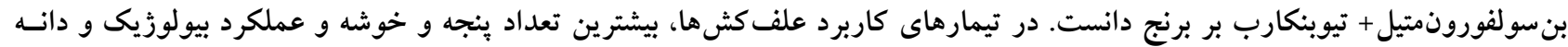

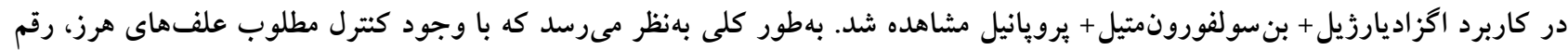

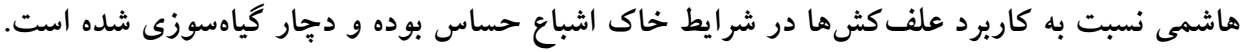

وازههاى كليدى: يرتيلاكلر، اگزاديارزيل، بنسولفورونمتيل، برويانيل، تيوبنكارب، سينوسولفورون

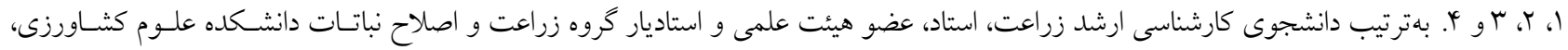
دانشخاه گيلان، كيلان، ايران asghari@guilan.ac.ir : مسئول مكاتبات: يست الكترونيكى : 


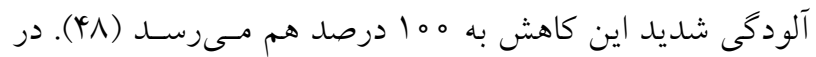

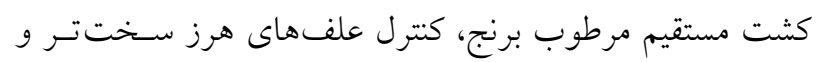

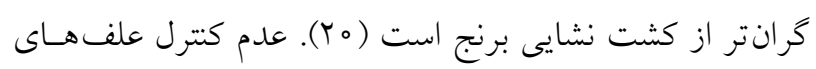

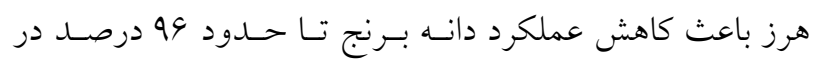

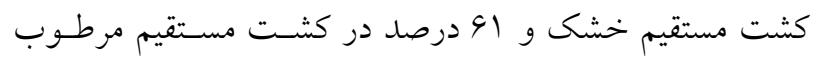

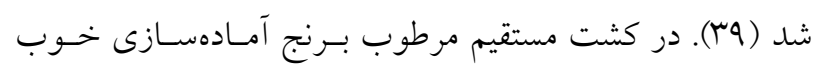

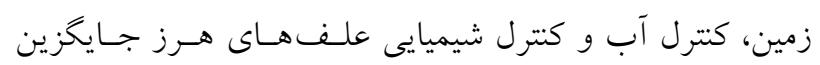

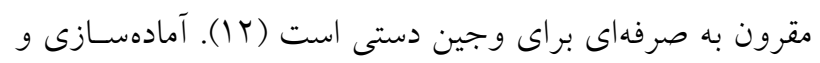
تسطيح زمين براى كنترل مـؤثر علـفـهـاى هـرز و موفقيـت در

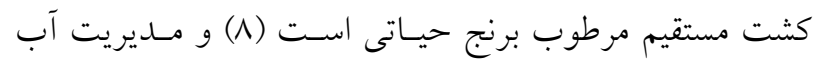

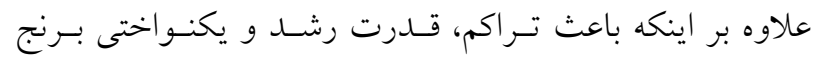
مىشود، باعث كارايى بهتر علفكشها نيز مىشود (آ).

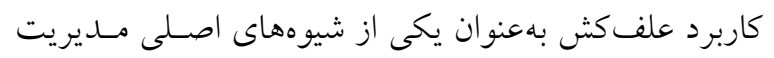

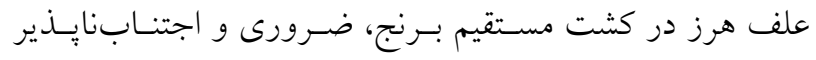

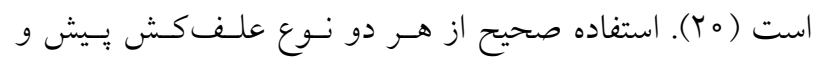

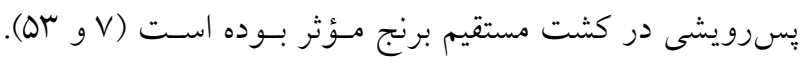

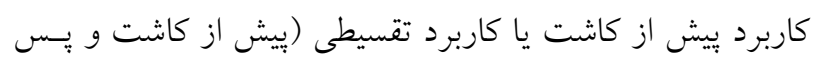

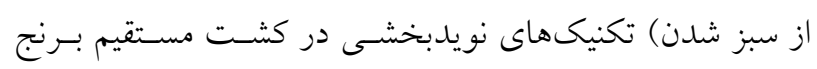

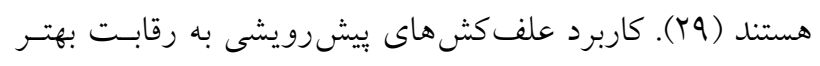

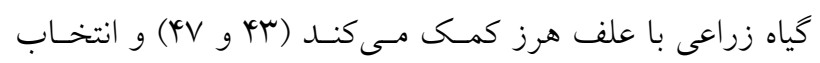

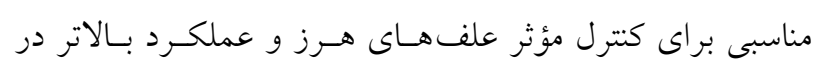

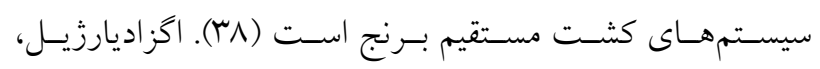

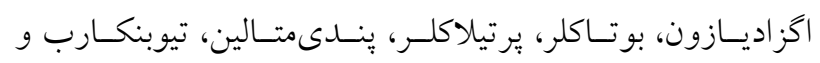

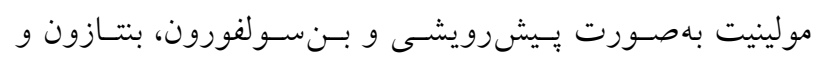
يرويانيل بهصورت يسرويشى در سراسر جهـان مـورد اسـتفاده

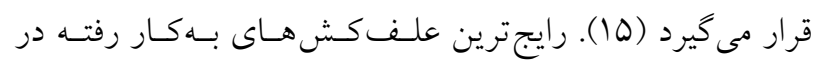

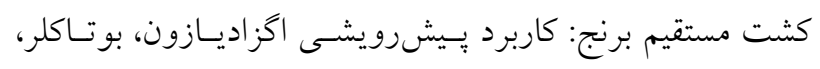

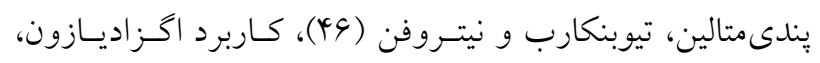

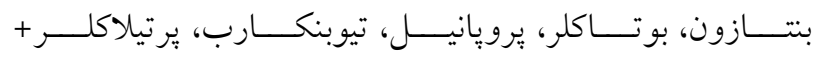

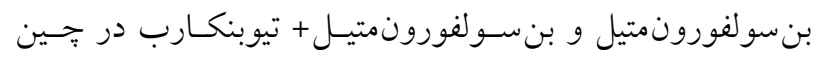

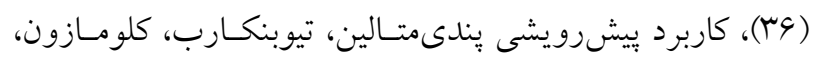

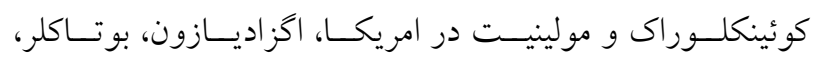

برنج محصولى استراتزيك بوده و استان كـيلان داراى مقــام دوم

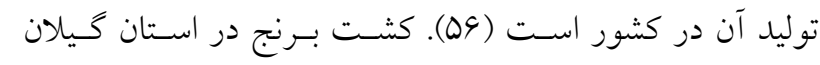

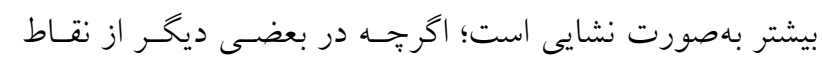

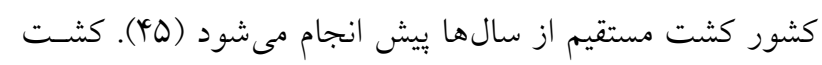

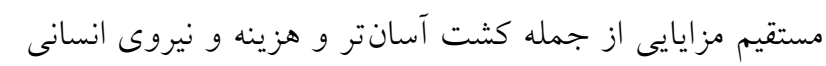

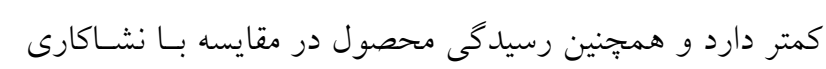

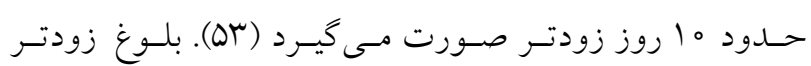
محصول در كشت مستقيم نسبت به نشاكارى فرصت بيشـترى را

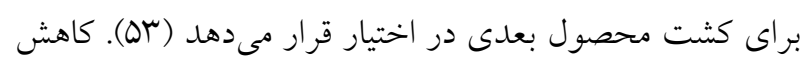

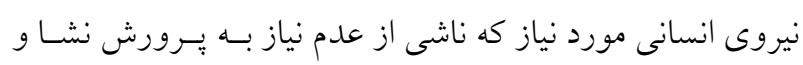

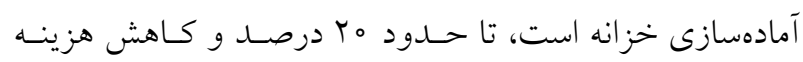

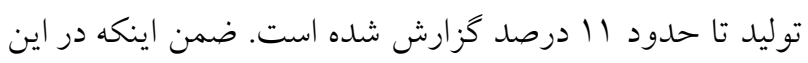

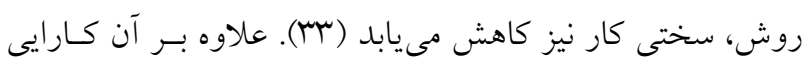

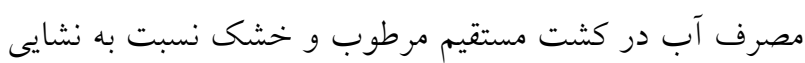
بيشتر است (r) - (1). كشت مستقيم برنج بيشتر به سه روش كشت مستقيم بذر در

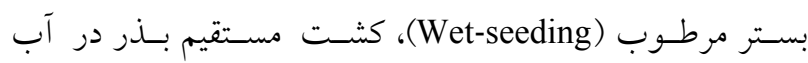
و كشت مستقيم بذر در حالت خشكهكارى (Water-seeding) صـورت مسى خيـرد (Try-seeding)

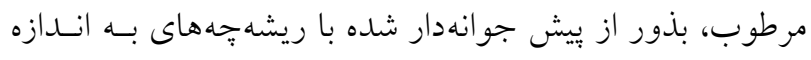

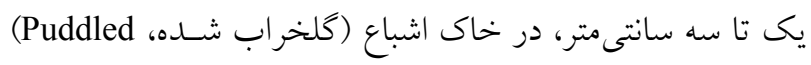

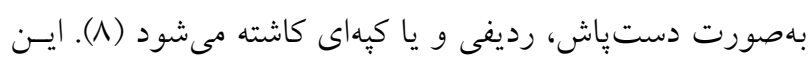

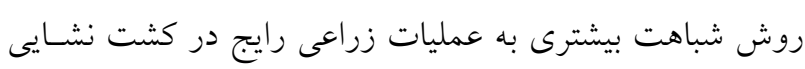

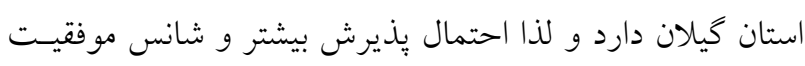

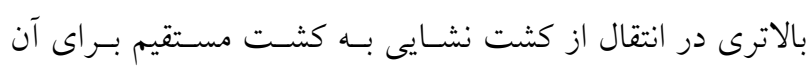
متصور است. علفهاى هرز يكى از محدوديتهاى جدى توليد در كشت

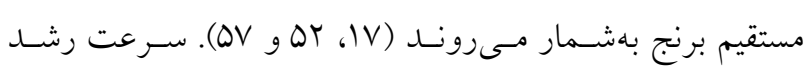
علف هاى هرز در كشت مستقيم نسبت به كشـت نشـايى بيشـتر

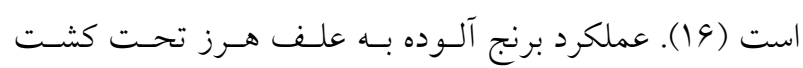

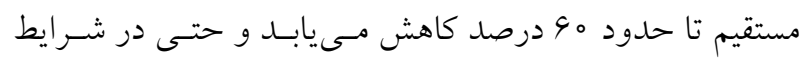




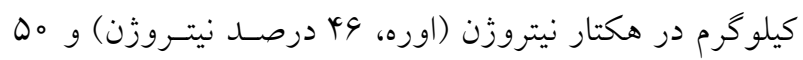

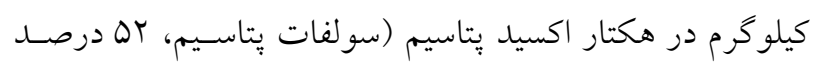

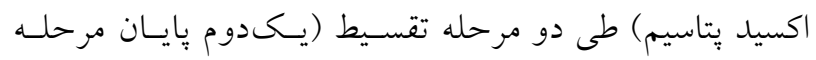

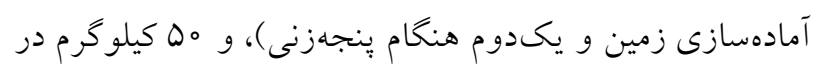

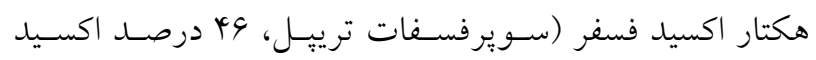

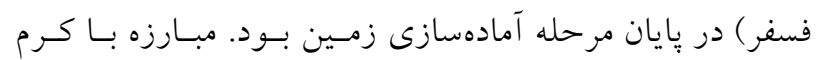

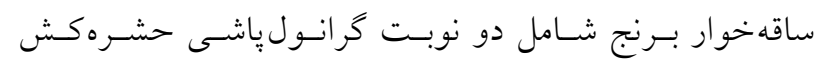

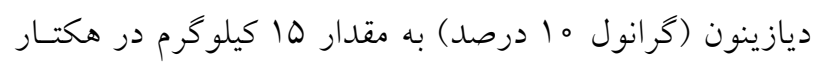
بود. كاشت بذرهاى جوانهدار شده به تعداد سه عدد در هر كيه

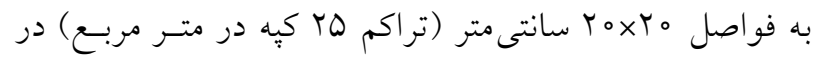
كرتهايى به ابعاد 9x/0 متر در اواسط ارديبهشت انجام شد. براى تمايز كرتها فاصله نيم متر و براى تمايز بلوكها فاصله

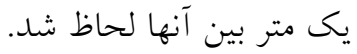
تيمـارهـا (Y ا تيمـار) شـامل كـاربرد مقــدار توصسيه شــده علـف كـشهــاى يرتيلاكلـر (Pt)، يرتيلاكلــــ +برويانيـل (PtPp)،

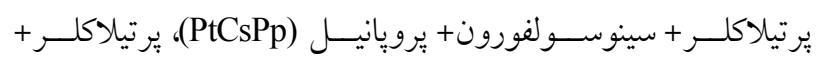

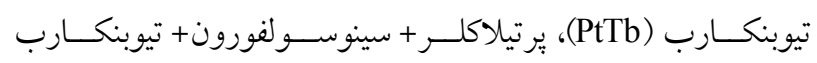

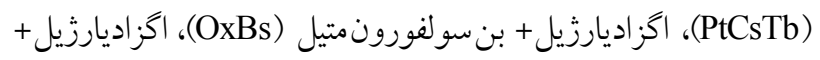

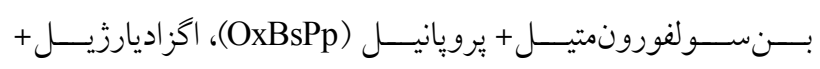

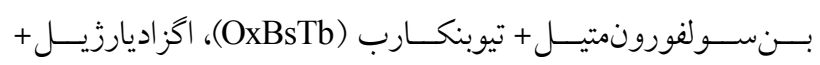
بنسـولفورونمتيـل + سينوسـولفورون+ يرويانيـل (OxBsCsPp)، از

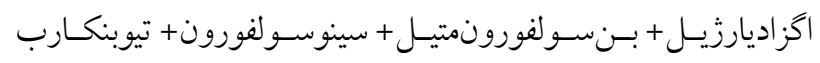
و همجنين سهبـار وجـين دستى (OxBsCsTb)

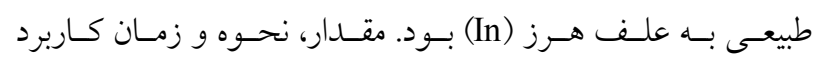
علف كشها در جدول الرائه شده است. براى بررسى اثر تيمارها بر جمعيـت علـفـهـاى هـرز، شـش

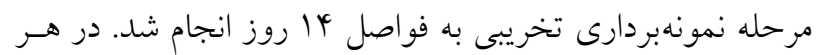

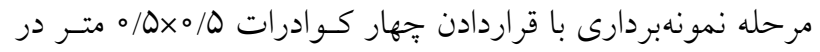

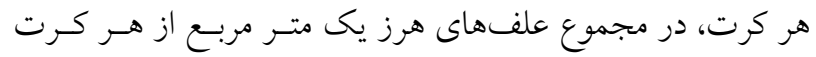
كفبر شده و پِ از شناسايى به تفكيك كونه و خشك شدن بـهـ مدت ^ץ ساعت در آون با دماى VD درجه سلسيوس توزين شـد

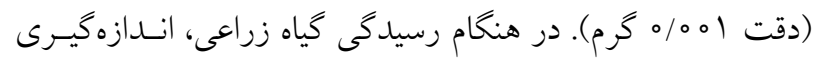

تيوبنكارب و مولينيت در سـريلانكا، و اخزاديـازون، برتيلاكلـر،

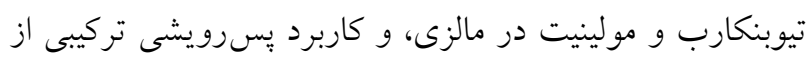

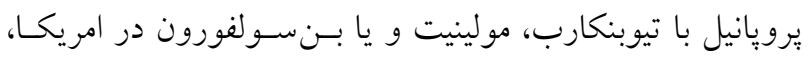

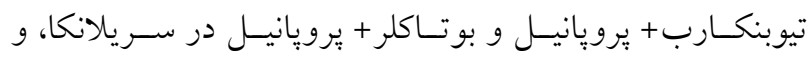

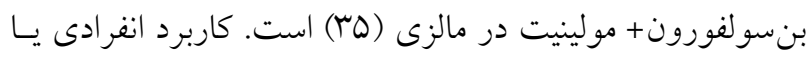
تركيبى برخى علف كشها در كشت مستقيم مرطوب برنج اغلب

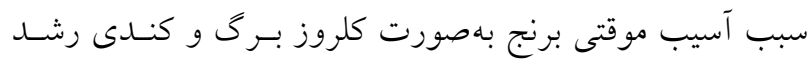

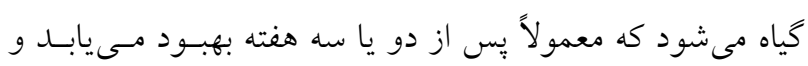

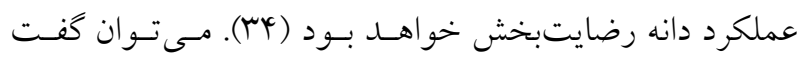

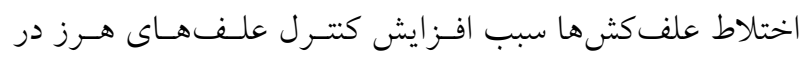
كَاهان مختلف ازجمله برنج شده است (YV) رقم برنج هاشمى يكى از ارقام محلى رايج در استان گَيلان

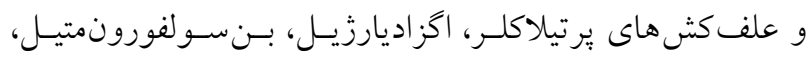

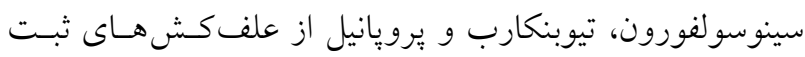

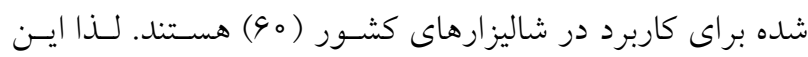

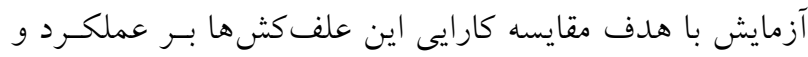

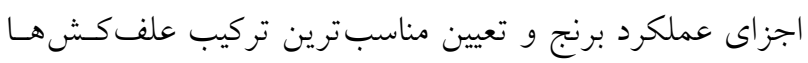

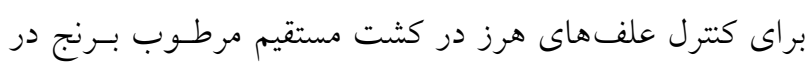
شرايط منطقه رشت انجام شد.

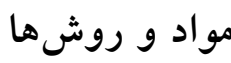

اين مطالعه در قالب طرح بلوكهاى كامل تصادفى با سه تكرار

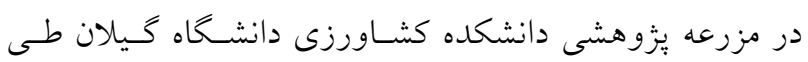

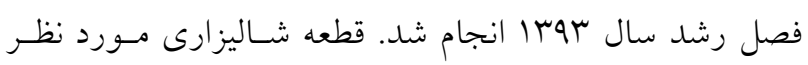

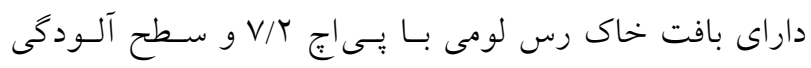

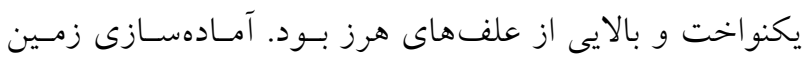

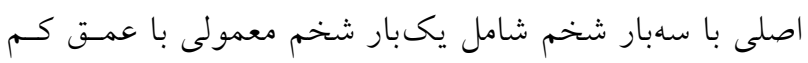

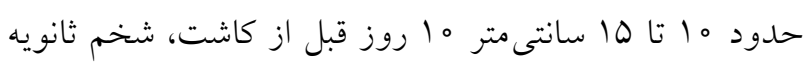

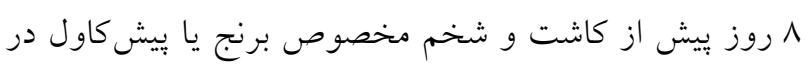

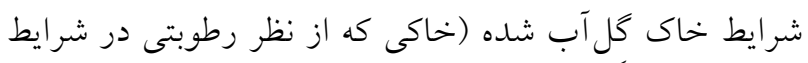

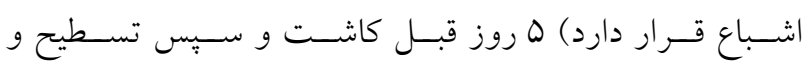

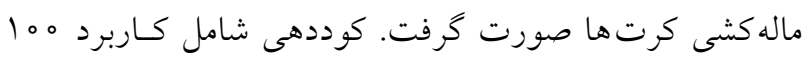


جدول ا. خصوصيات، مقدار، نحوه و زمان كاربرد علفكشهاى به كار رفته در آزمايش"

\begin{tabular}{|c|c|c|c|c|c|}
\hline زمان مصرف & مقدار توصيهشده & 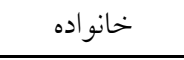 & 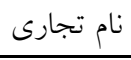 & 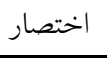 & نام علف كش \\
\hline قبل از رويش (r روز بعد كاشت) & امولسيون r درصد، هو گرم ماده مؤثر در هكتار & 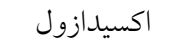 & 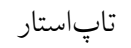 & $\mathrm{Ox}$ & 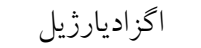 \\
\hline قبل از رويش (r روز بعد كاشت) & امولسيون •ه درصد، هم گرم ماده مؤثر در هكتار & 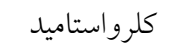 & ريفيت & $\mathrm{Pt}$ & يَّرتيلاكلر \\
\hline بلافاصله بعد از رويش (با روز بعد كاشت) & امولسيون ه9 درصد، مب گرم ماده مؤثر در هكتار & سولفونيل اوره & 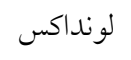 & Bs & 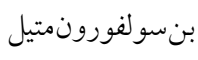 \\
\hline 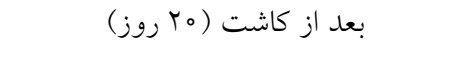 & 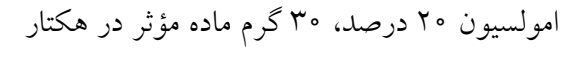 & سولفونيل اوره & ستاف & Cs & 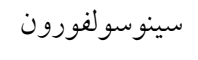 \\
\hline بعد از كاشت (مبر روز) & 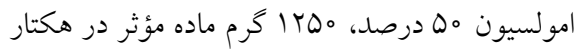 & 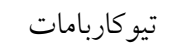 & 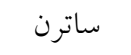 & $\mathrm{Tb}$ & 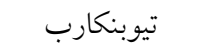 \\
\hline بعد از كاشت (ro روز) & امولسيون צr درصد، ه4 کرم ماده مؤثر در هكتار & 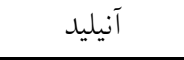 & 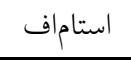 & $\mathrm{Pp}$ & 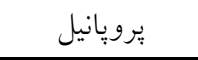 \\
\hline
\end{tabular}

* در اين آزمايش از علفكشهاى موجود در بازار كه در دسترس كشاورزان قرار دارد، استفاده شد.

،(Paspalum distichum L.) (Cyperus difformis L.) بارهنخ آبى (قاشقواش، . Alisma plantago L) و تيركمان آبسى (Saggitaria trifolia L.)

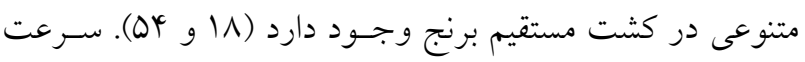
رشد علفهاى هرز در كشت مستقيم نسبت به كشت نشايى در شرايط غرقابى بيشـتر اسـت (م ا و 19). كشـت مسـتقيم بـرنج منجر به تغيير فراوانى نسبى كونهاى علف هرز شـده اسـت. سوروف و اويارسلام بذرى ساز كارى بالايى به شرايط كشت مستقيم از خود نشان مى دهند. جنس Echinochloa بهدليـل

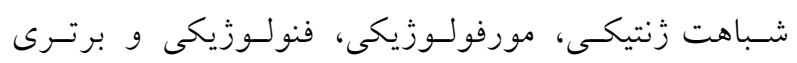

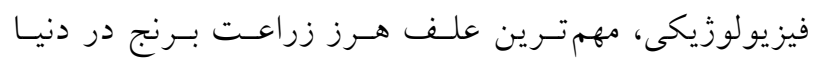

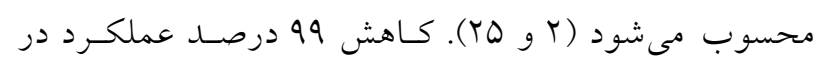
كشت مستقيم مرطوب برنج درنتيجه آلودگى بـه علـف هــاى هـرز Echinochloa oryzoides و كـز ارش E. phyllopogon شده است (YY). امين يناه (Y) اظهار داشت كه با افزايش تراكم

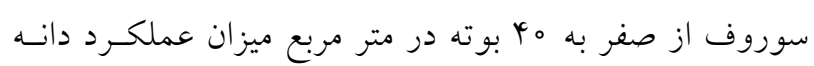

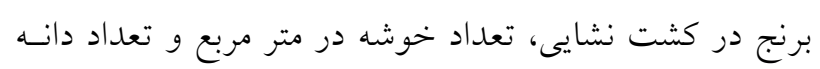

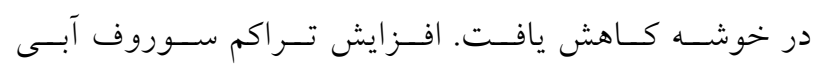

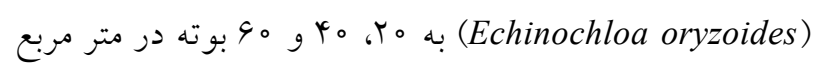

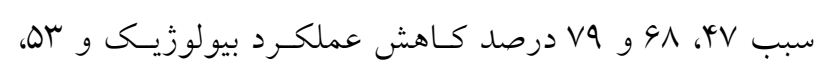
و Vo

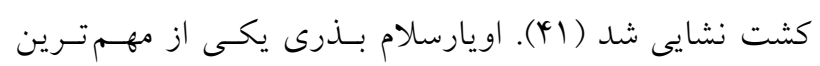
علف هاى هرز يـكسـاله در كشـت بــنج در جهـان و شـمال كشور (مهو مهو) است. بنـدواش (Paspalum distichum L.) كياهى است جندساله و تجهاركربنه كه توسـط بـــر، ريـزوم و
ارتفاع بوتههاى برنج از سطح زمين تا نوى بلنـدترين خوشـه در "ينج كيه تصادفى از هر كرت، و شـمارش تعــاد كـل ينجسهـهـا،

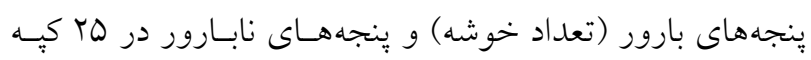

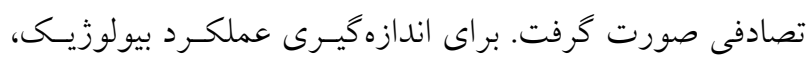

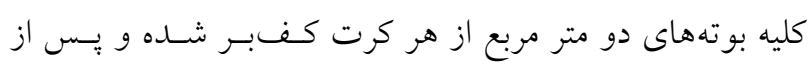

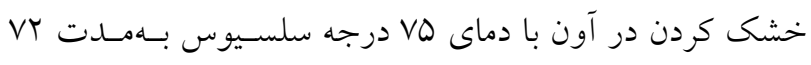

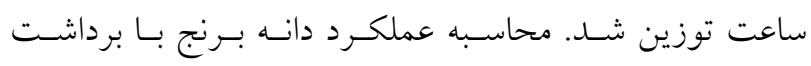

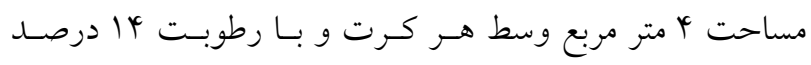
انجام شد. شاخص برداشت با تقسيم وزن خشك دانسه بـر وزن

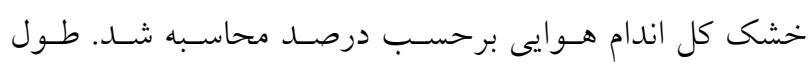
خوشه، تعداد دانههاى ير و بوك در ها خوشه تصـادفى از هـر

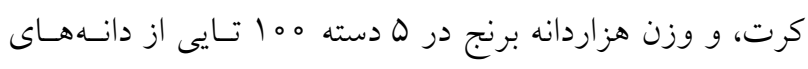
جدا شده هر كرت بر اساس رطوبت ع ا درصد اندازهذيرى شد. مرتبسازى دادهها در نرمافزار Excel، تجزيه واريانس دادهها با استفاده از رويةٔ مدل خطى عمومى در نرمافزار SAS, ver. 9.1 انجام شد. مقايسه ميانخينها با استفاده از آزمون محافظت شده در سطح احتمال ه درصد صورت كرفت. LSD نمودار مقادير صفات اندازهيرى شده طى فصل رشد، با استفاده از نرمافزار Sigma Plot, ver. 11 رسم شد.

\section{نتايج و بحث}

\section{بررسى جامعه علفهاى هرز}

كونهاى غالب علف هرز

مهم ترين كونه هاى علف هرز مشاهده شده شـامل سـوروف (Echinochloa crus-galli L.) 
جدول Y. نام علمى و گروههاى كاركردى علفهاى هرز غالب مشاهده شده در مزرعه برنج

\begin{tabular}{|c|c|c|c|c|c|c|c|}
\hline \multicolumn{4}{|c|}{ كروههاى كاركردى } & \multirow{2}{*}{ 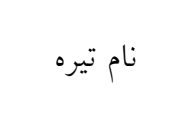 } & \multirow{2}{*}{ ن ام علمى } & \multirow{2}{*}{ 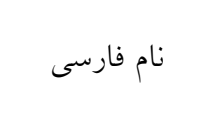 } & \multirow{2}{*}{ رديف } \\
\hline درجه سماجت & مسير فتوسنتزى & شكل رويشى & 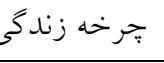 & & & & \\
\hline سمج & جهار كربنه & 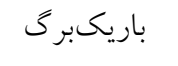 & 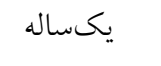 & Poaceae & Echinochloa crus-galli. L. & سوروف & 1 \\
\hline سمج & سهربنه & جنى & يكساله & Cyperaceae & Cyperus difformis L. & اويارسلام بذرى & r \\
\hline سمج & جهار كربنه & باريكبرى & جندساله & Poaceae & Paspalum distichum L. & بندواش & r \\
\hline سمج & سه كربنه & يهنبرى & جندساله & Alismataceae & Alisma plantago-aquatica L. & 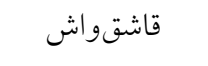 & $\varphi$ \\
\hline 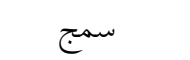 & سهربنه & يهنبرى & جندساله & Alismataceae & Sagittaria saggitifolia L. & 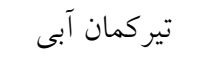 & 0 \\
\hline
\end{tabular}

استولون تكثير مىيابد. اين علف هرز در مزارع بـرنج بيشـتر سوروف

در كليه تيمارهاى آزمايشى بــا بيشـرفت فصـل رشـــ از تعـداد

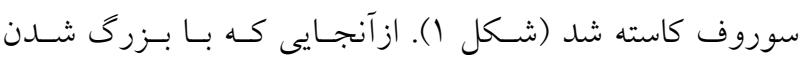
بوتهها در واكسنش بـهـ رقابـت درون و بـين گونـهاى تعـدادى از كياهان از بين مىروند، جنين كاهشى مورد انتظار بود. همجنــين با كاربرد علف كشهاى مختلف و نيـز در شـرايط عـدم كنتـرل علف هرز زيست توده سوروف طى فصل رشـــ افـزيش يافـت. در اولين نمونهبردارى (l أ روز يس از كاشت)، علفكـشهـاى

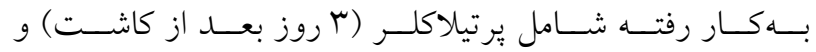
اكزاديارزيل + بنسولفورونمتيل (r روز بعـد از كاشـت + ب روز بعد از كاشت) بود. تراكم و زيست توده علف هرز سـوروف در كاربرد علف كش برتيلاكلر ه اب بوته در متر مربع و ro٪ ا كرم

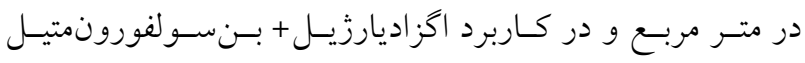

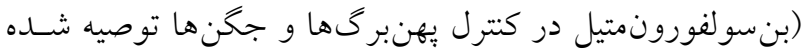
است) سזr بوته در متر مربـع و N/19 گـرم در متـر مربـع بـود. مقايسه دو كروه حاكى از نداشتن تفاوت معنىدار در كاربرد آنها بود؛ اخرجه به نحو معنى دارى بيشتر از شرايط وجين (تراكم 19 بوته در متر مربع و زيستتوده ||/1/ گرم در متر مربع) بـود. بـا

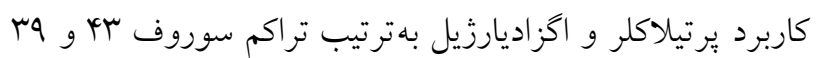

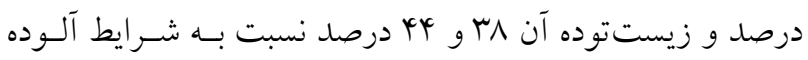
به علف هرز كاهش يافت و اين مقادير بهترتيب كاه و هه درصـد

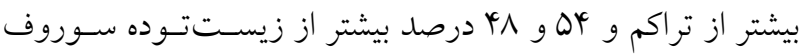
در تيمار وجين دستى علفـهاى هـرز بودنــــ ايسن نتيجـه بيـانكر وجود آلودگى بالاى سـوروف در عا روز يسس از كاشـت اسـت.

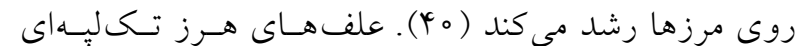
بارهنخ آبى (قاشقواش) و تير كمان آبسى، داراى بـركهـــ

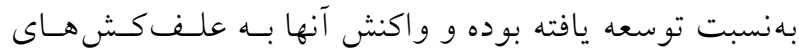

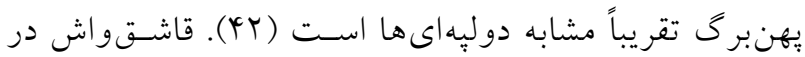
اوايل رشد برنج سبز مى شود؛ اما با ينجهزنى و افزايش تراكم برنج و ساير علفهاى هرز داراى رشد رويشى زياد و ارتفاع بالاتر، تراكم آن در اثر رقابت كاهش مى يابد (ه). علفهــاى هرز بهـنبرى تراكم بسيار كمى داشتند كه مى توانـــ بـهدليـل رقابت ساير علف هاى هـرز بـهـويـزه سـوروف و اويارسـلام باشد. با توجه به كمبـودن تـراكم بنــواش، تيركمـان آبسى و قاشقواش (كمتر از دو بوته در متر مربع)، از بررسى انفرادى آنها جشمى يوشى شده و در جمعيت كل علف هاى هرز منظور

\section{تراكم و زيست توده علفهاى هرز}

نتايج تجزيه واريانس دادهها در مراحل مختلف نمونهبـردارى و

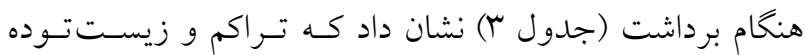

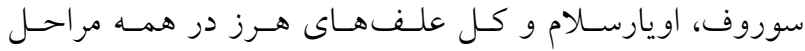
نمونهبردارى تحت تأثير كاربرد علف كشها قرار گرفت. اكبـر و

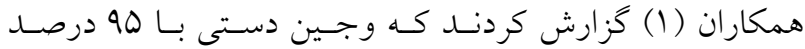
كاهش تراكم و وزن خشك علف هاى هرز بهتر از بقيـه تيمارهـا عمل كرد. كنترل شيميايى سبب بـيش از •م و كنتـرل مكـانيكى سبب VY درصد كاهش تراكم علفهاى هرز نسـبت بـه شـاهد آلوده به علف هرز در كشت مستقيم برنج شد. 
جدول r. نتايج تجزيه واريانس (ميانگين مربعات) اثر علف كثها a بر علفهاى هرز برنج طى مراحل نمونهبردارى

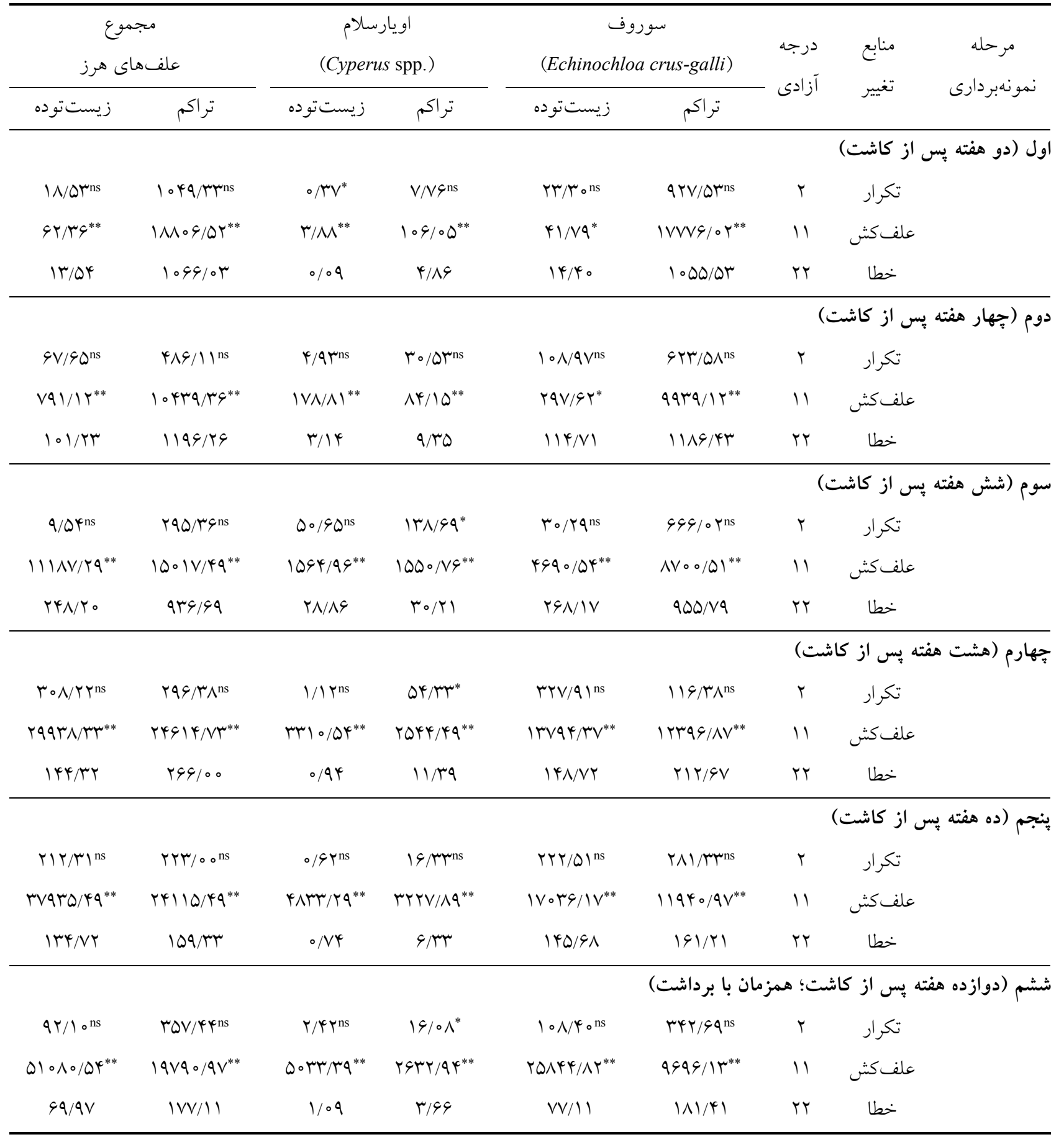

a

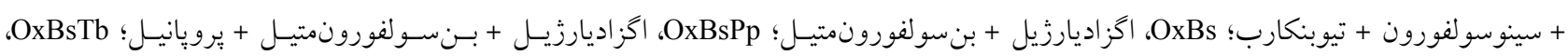

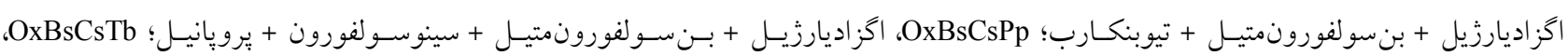

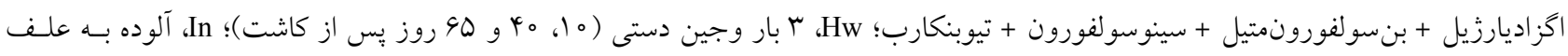

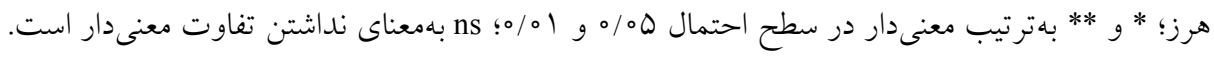



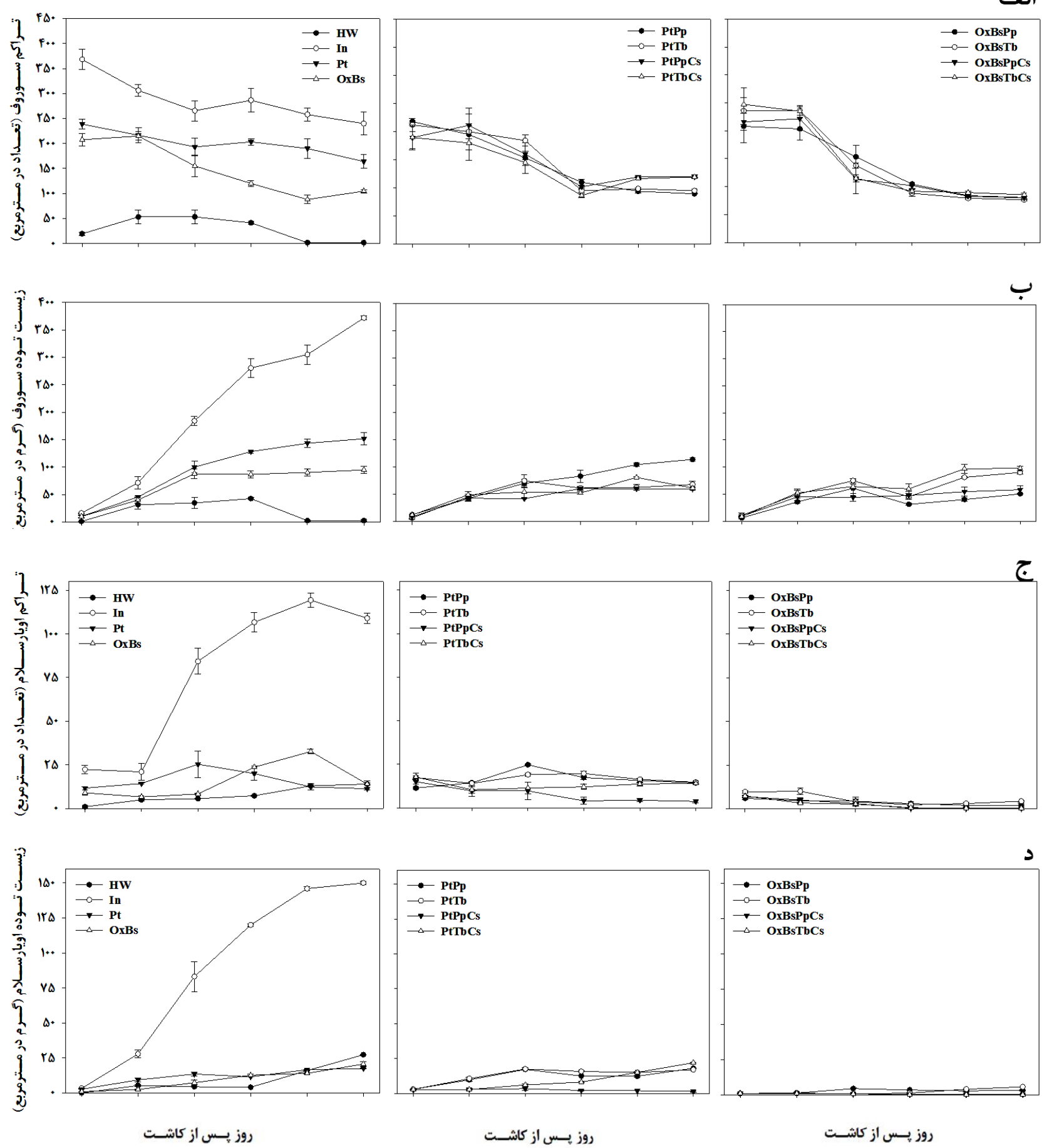

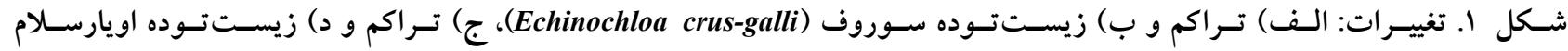
(Cyperus difformis)

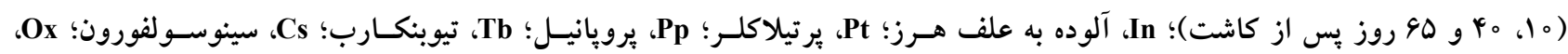
اكزاديارزيل؛ Bs، بنسولفورونمتيل و خطوط عمودى نشاندهنده خطاى استاندارد هستند.) 

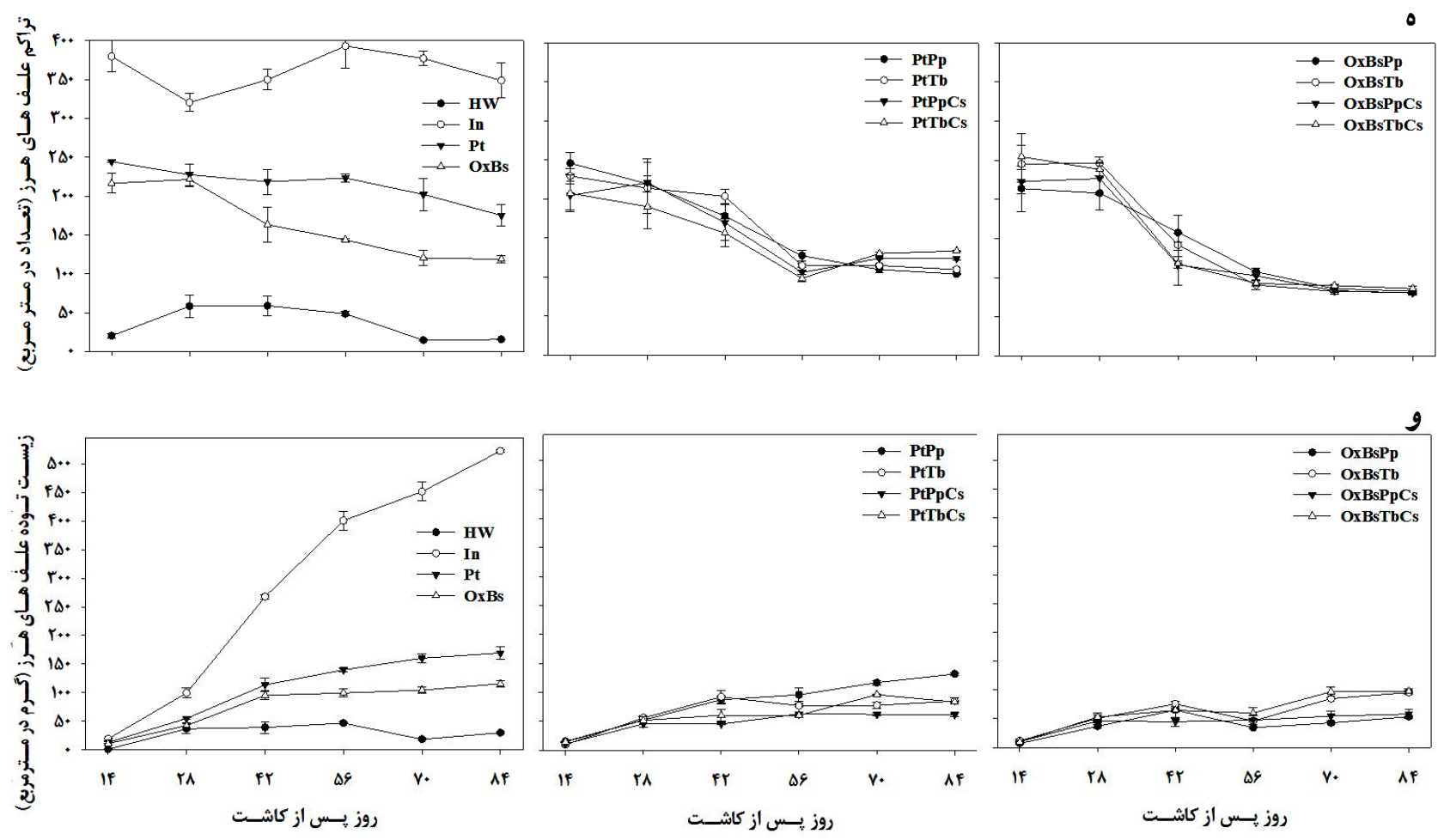

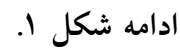

علف كشها در كـاهش تـــاكم سـوروف در مقايسـه بـا شــايط

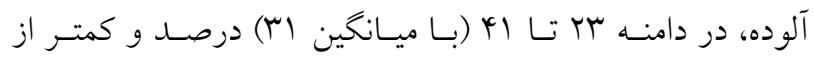
كارايى وجين (N درصد) بود. اين رقم بر اسـاس زيسـت بــوده

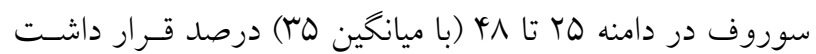
كه فاقد تفاوت معنى دار با كارايى وجين (كاه درصد) بـود. ايسن

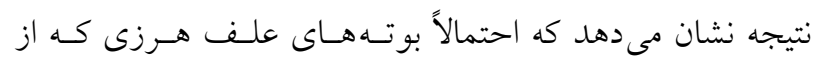
وجين فرار كردهاند، با رشد بيشتر سبب كاهش كارايى وجين در كتترل سوروف شدهاند. شاخص زيست توده علفهـاى هـرز در مقايسه با تراكم، بــراى نشـان دادن كـاهش عملكـرد يـك گيـاه بهواسطه رقابت، از دقت بالاترى برخوردار است ( (1)). در واقـع وزن علف هاى هرز منعكس كننده عو امل رشــى تسـخير شـده بلهوسيله علف هرز است (Y9).

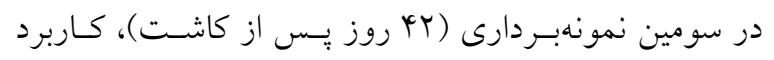
علف كش برويانيل و تيوبنكارب (هر دو مب روز يس از كاشت)

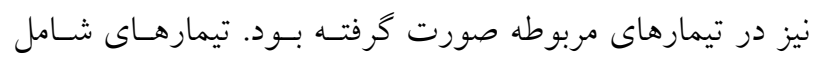
اكزاديارزيل، در كنترل تراكم سوروف بهتر از تيمارهـاى شـامل يرتيلاكلر عمل كردند (بهترتيب هسا و 19 بوته در متر مربـع).
دليل بالا بودن جمعيت علف هاى هرز در كشـت مسـتقيم بـرنج،

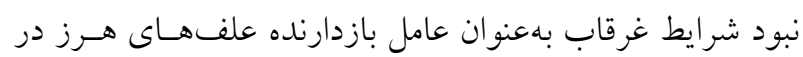
ابتداى رشد و نيز تقدم يا همزمانى ظهور علف هـرز نسـبت بـه برنج است (IV). سوروف در كشت مستقيم در مقايسه با كشت نشائى توانايى رقابت بالاترى دارد (†^). در دومين نمونهبردارى

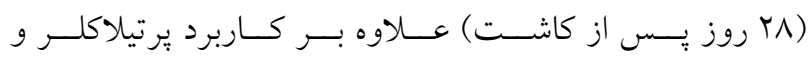

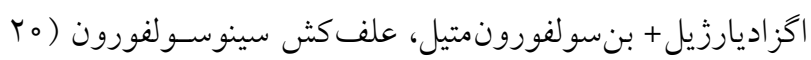
روز يس از كاشت) نيز در تيمارهاى مربوطه وارد شــ. در ايسن

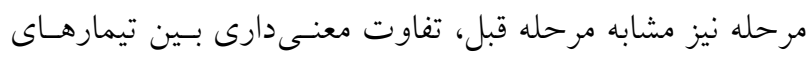

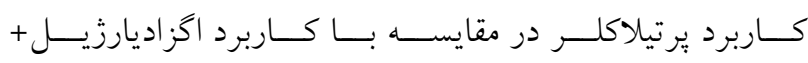
بنسولفورونمتيل (با ميانخين تـراكم الب بوتـه در متـر مربـع و زيست توده YY/VG كرم در متر مربع) مشاهده نشد. نظر به اينكه علف كش سينوسولفورون براى كنترل يهنبـركهـا و جخـنهـا توصيه شده است (90)، اثر نداشـتن ايسن علـفــش در بهبـود كنترل سوروف مورد انتظــار بـود. همجنهـين در شـرايط كـاربرد علف كشها هر زّند تراكم سوروف بالاتر از شرايط وجين بـود؛ اما زيست توده علف هرز تفاوت معنى دارى نشان نــاد. كـارايى 
به برويانيل مؤثر است.

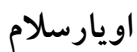

در تيمار آلوده به علف هرز با بيشرفت فصـل رشـــ تـا مرحلـه

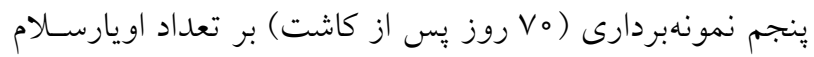

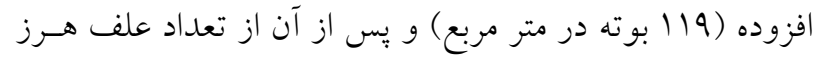
كاسته شد (شكل (). با توجه به بالا بـودن دماهـاى بحرانس در

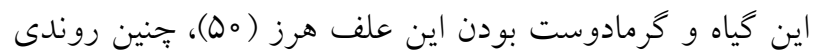
مورد انتظار بود. در شرايط كاربرد علف كشهاى مختلـف بستهـه

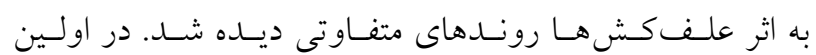

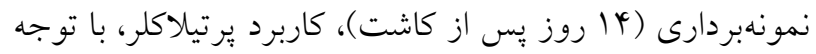

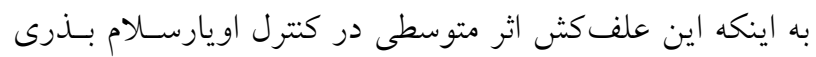

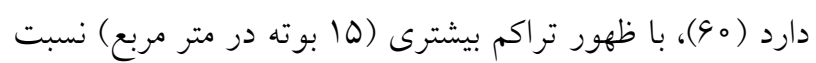

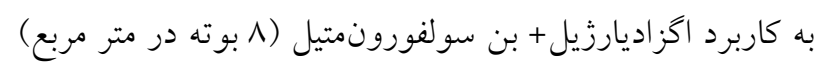

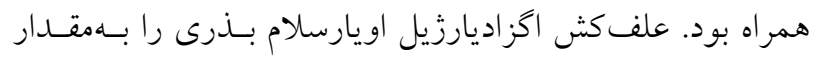

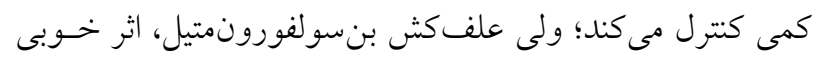

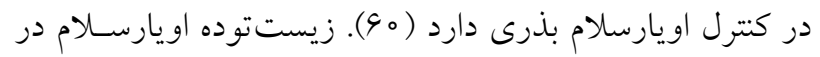

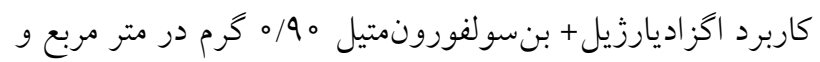

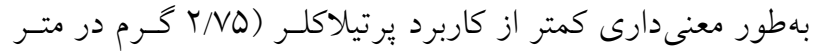

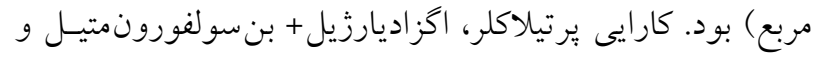
وجين دستى اويارسلام در كاهش تراكم سٓ، بهو و 9 درصـد و بر اساس زيست تـوده VV، VV و 99 درصـد نسـبت بـه شـرايط

$$
\text { آلوده به علف هرز بود. }
$$

در دومين نمونهبردارى (YN روز بِ إز كاشت)، علفكـش سينوسولفورون نيز به تيمارهاى مربوطه اضـافه شــده بـود. ايسن علف كش براى كتترل بهنبر گها و جخن ها به كار مىرود (90)،

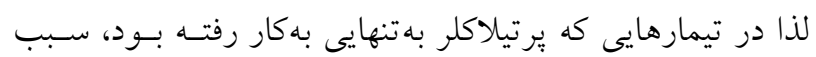

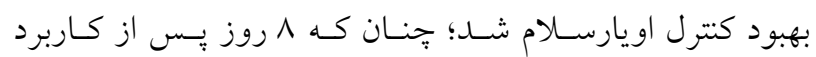

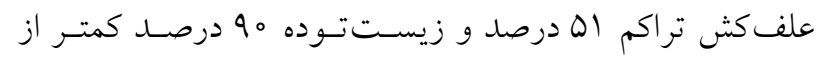

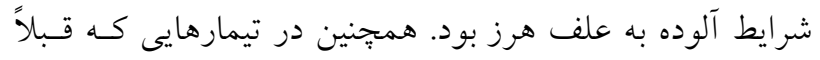

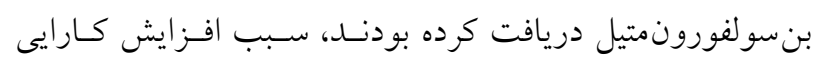

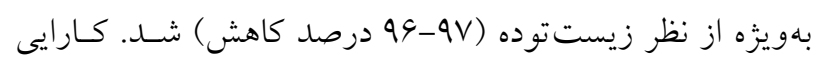

تراكم سوروف نسبت به شاهد آلوده بـه علـف هـرز بـا كـاربرد

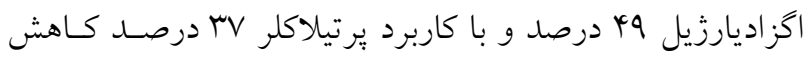

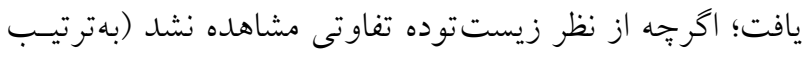

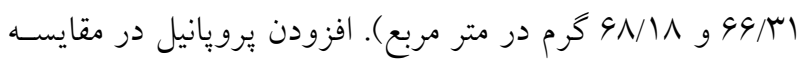

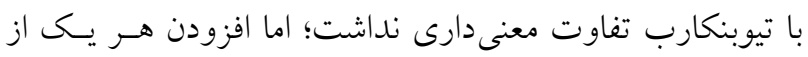
اين دو علف كش به برتيلاكلر و اخزاديارزيل سبب بهبود كنتـرل

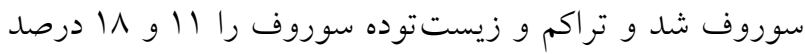
بيشتر از كاربرد انفرادى اين علف كش ها كاهش داد. مقايسـهـ بـا تيمار وجين دستى علـف هـاى هــرز نشـان داد كـهـ اثـر كـاربرد

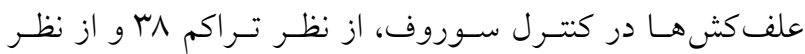

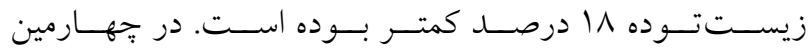
نمونهبردارى (هو روز پِ از كاشت) تيمارهاى شامل يرتيلاكلر

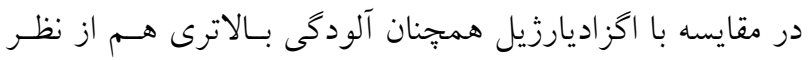

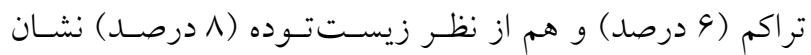

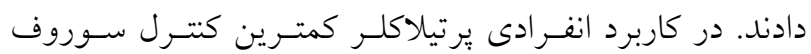

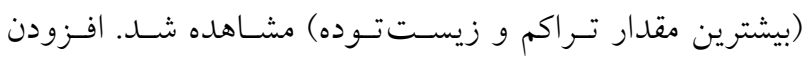

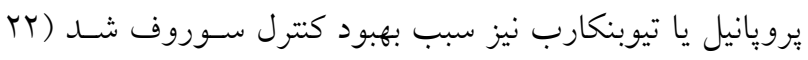

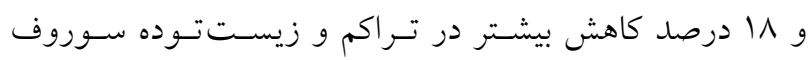

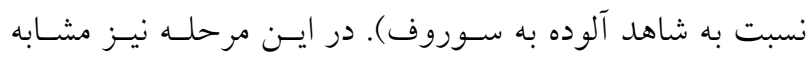
مراحل قبل، كارايى وجين به نحسو معنسى دارى بيشـتر از كـاربرد

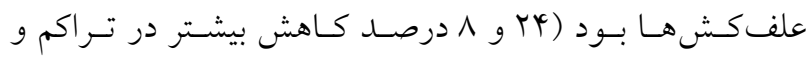

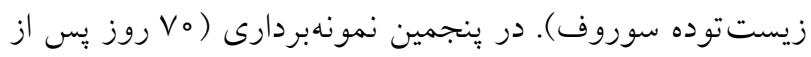

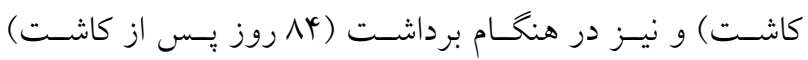

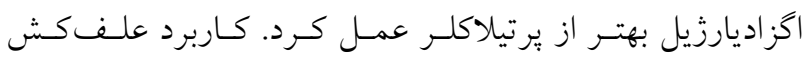

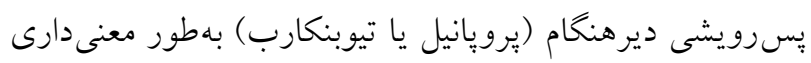

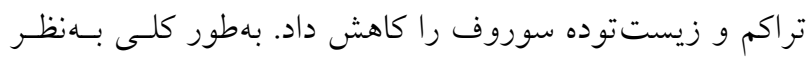

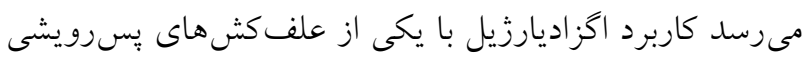

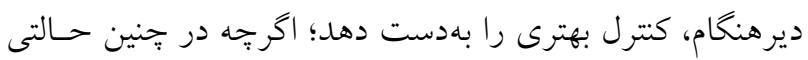

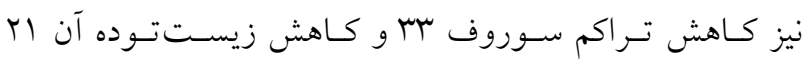
درصد كمتر از وجين دستى بوده است. تالبرت و همكاران (DN)

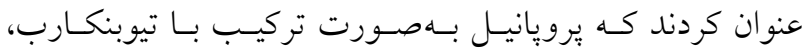
مولينت يا كوئينكوراى در كنترل علف هاى هرز سوروف مقـاوم 
اواسط دوره رشد بههمراه داشته باشد و بعد از آن جلـوكيرى از

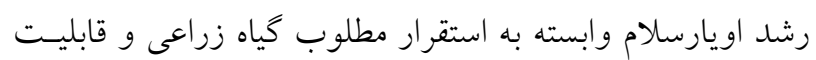

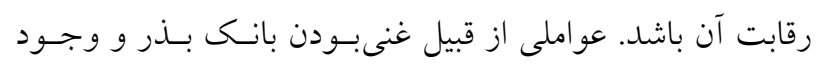

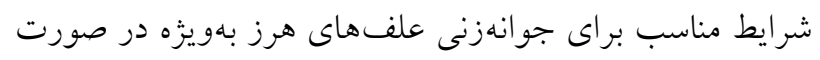

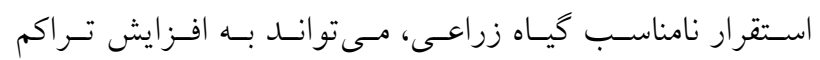

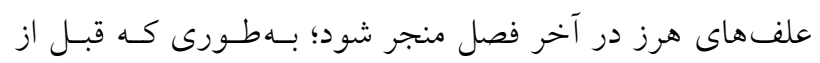

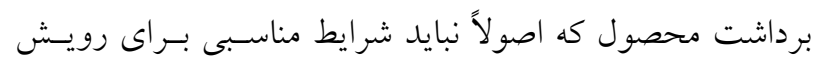

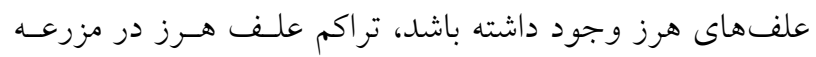

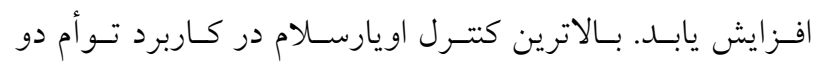
علف كش سولفونيل اوره حاصل شد و حداكثر كاريى به 99/99

\section{كل علفهاى هرز}

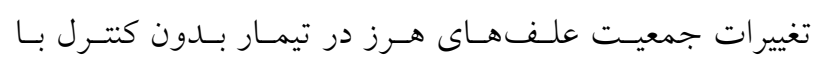

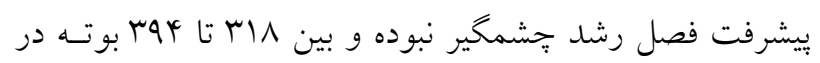

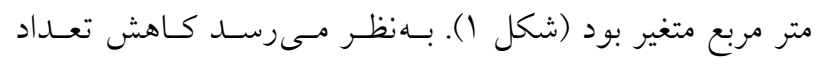

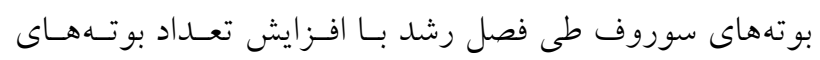

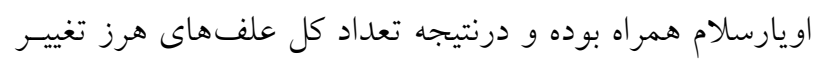

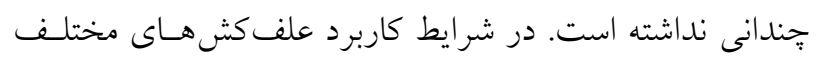

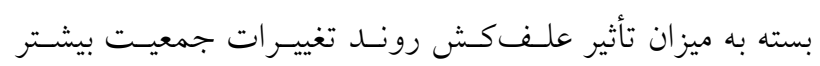

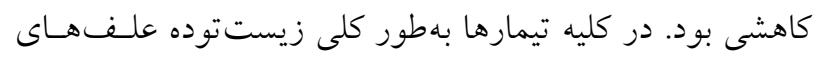

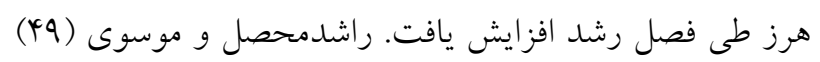

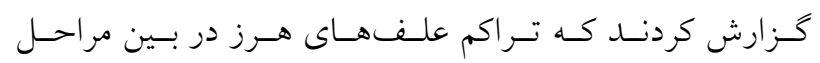

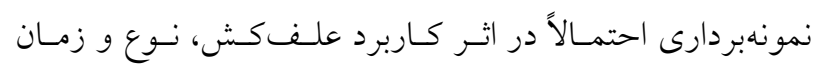

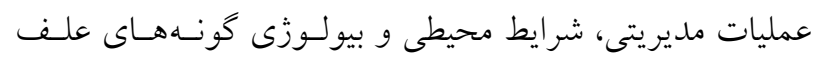
هرز موجود تحت تأثير قرار مى گيرد.

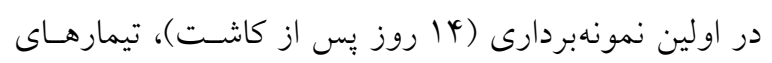

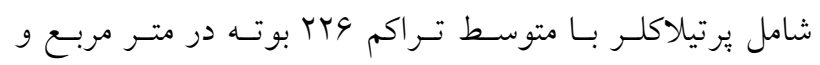

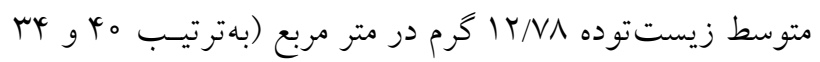

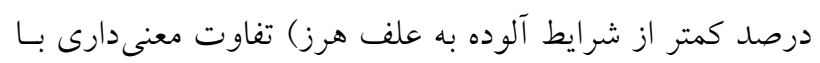

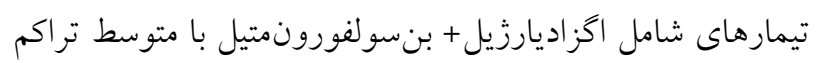

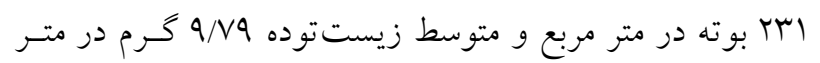

علف كش (ميزان كاهش نسبت به شاهد آلوده به علف هـرز) در

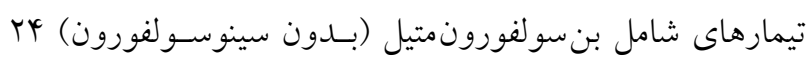

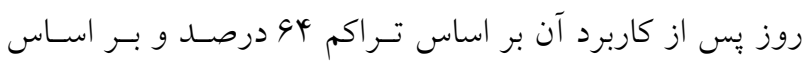

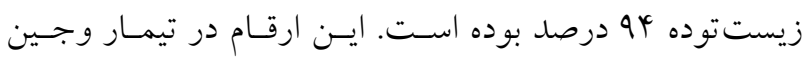

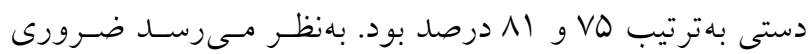

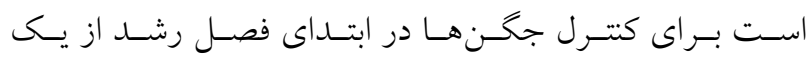
علف كث اختصاصى استفاده شود.

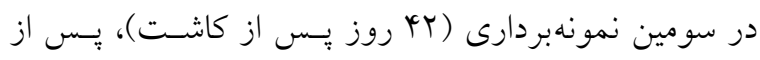

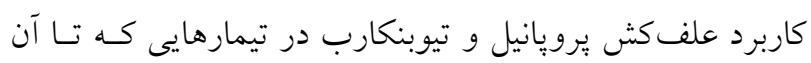
زمان فقط يرتيلاكلر دريافت كرده بودند، با وجود افزايش تـراكم

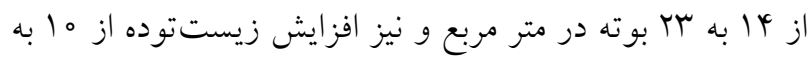
IV

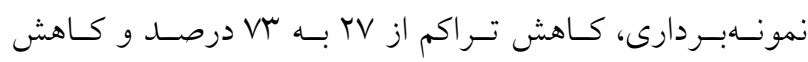

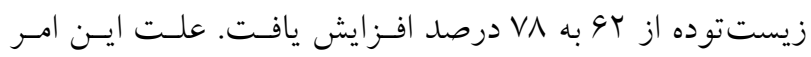

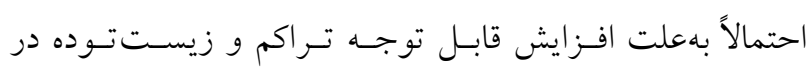

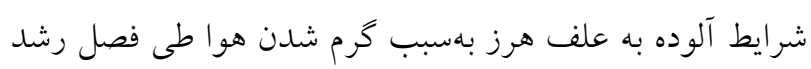
بوده است. علف كش يرويانيل و تيوبنكارب اثر كمسى در كنتـرل

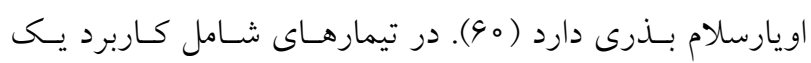

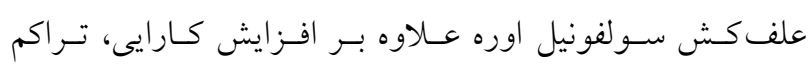

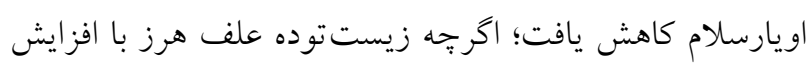

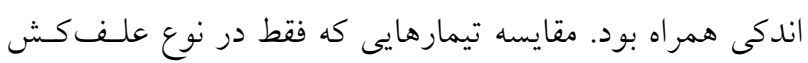

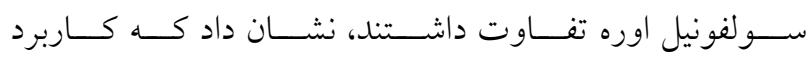

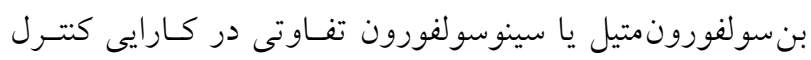

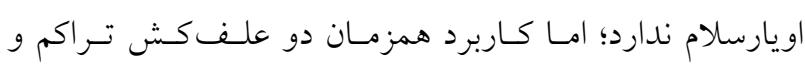
زيست

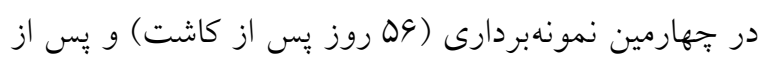

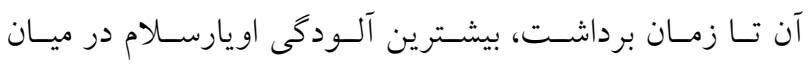

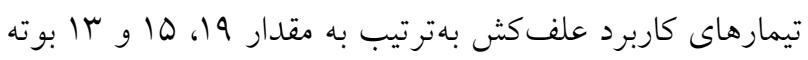

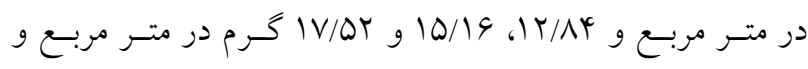

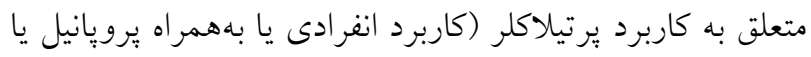

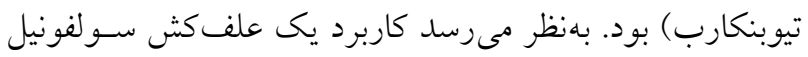

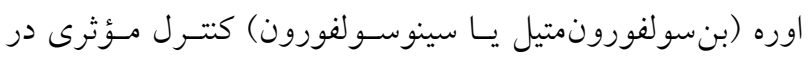




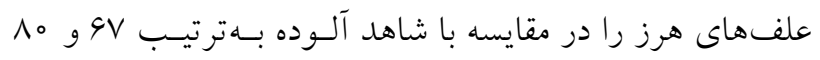

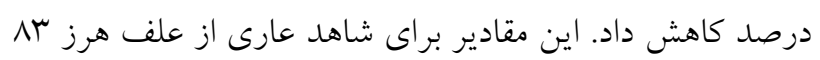

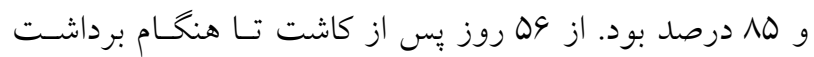

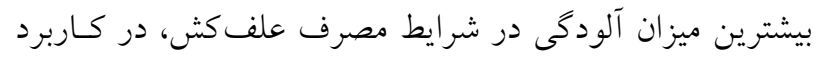

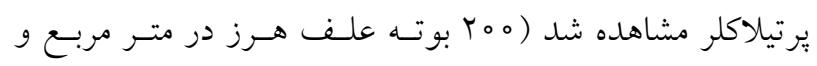

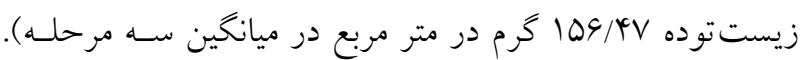

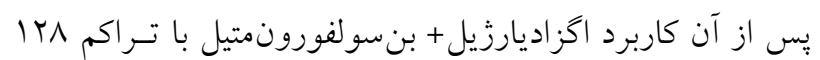

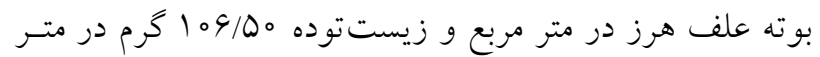

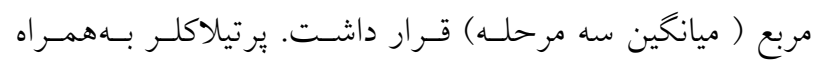

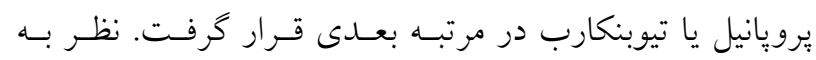

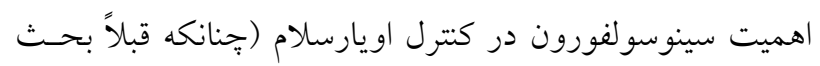
شد)، كاربرد اين علف كش در تيمارهاى كفته شده سـبب بهبـود

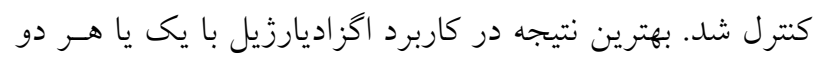

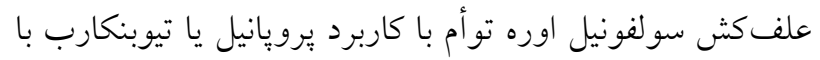

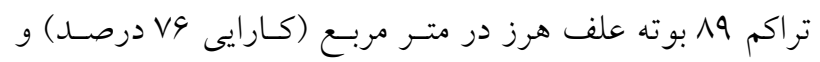

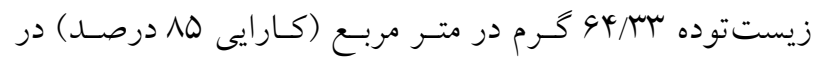

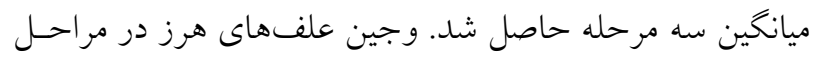

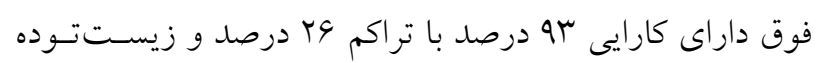
س ب// آ كرم در متر مربع بود.

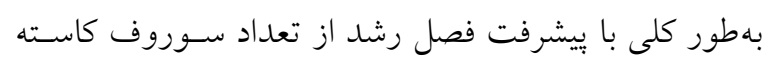
اما زيست توده آن افزايش يافت. در مـورد اويارسـلام در تيمـار

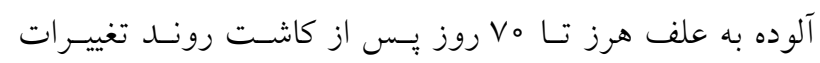

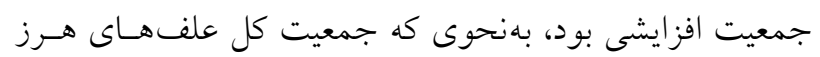

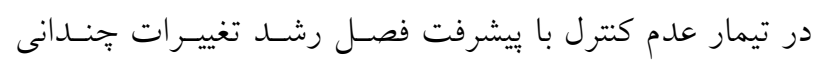

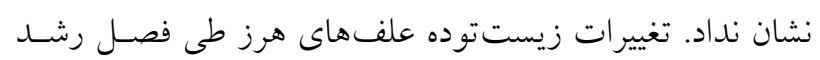

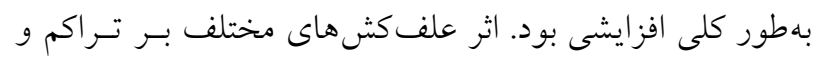
زيست توده علفهاى هرز متفاوت بود؛ بـهنحسوى كـه تـراكم و

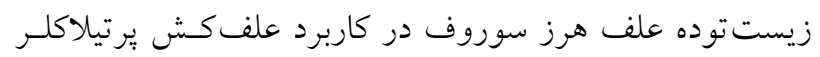

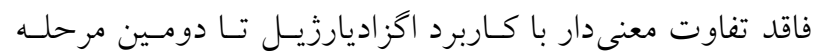

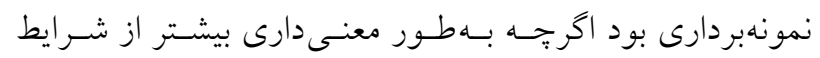

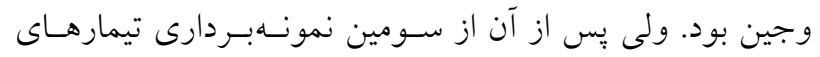

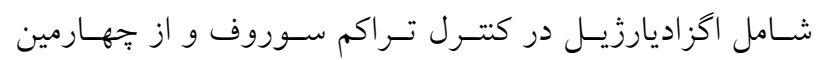

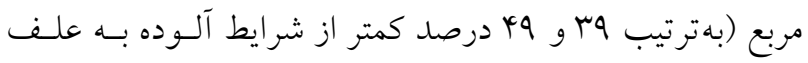
هرز) نداشتند. كارايى وجين علف هاى هرز در ايسن مرحلـه 90

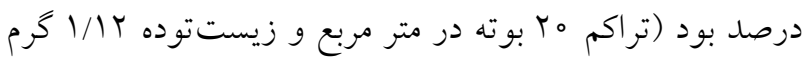

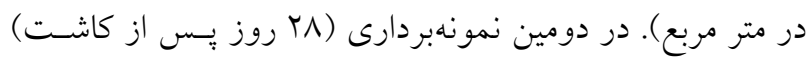

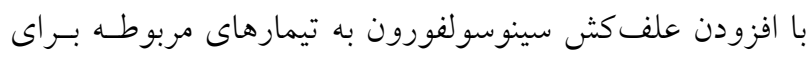

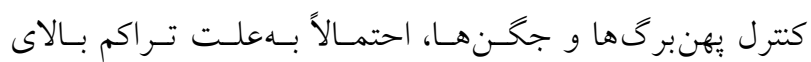

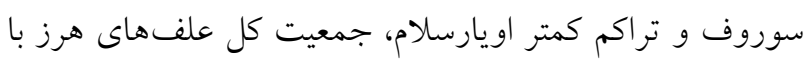

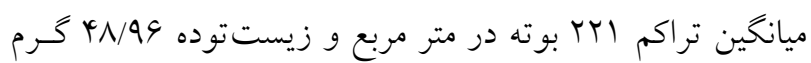

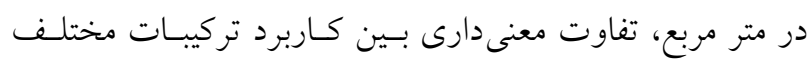

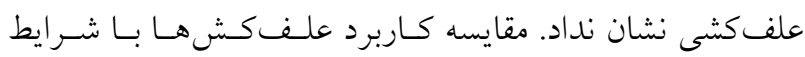
عارى از علف هرز حاكى از تفاوت تراكم؛ اما تشابه زيست توده كل علف هرز داشت؛ بهنحوى كه كاهش تراكم نسبت به شرايط

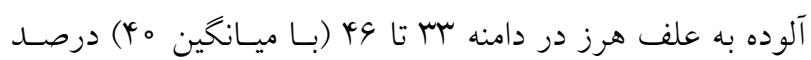

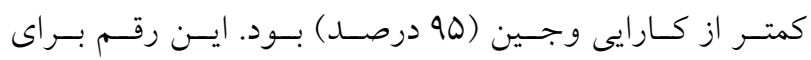

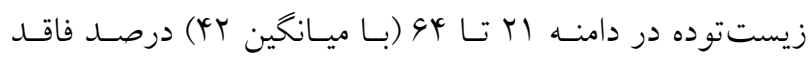

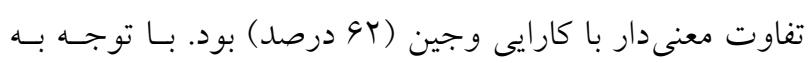

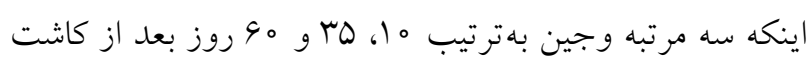

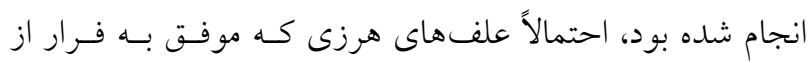

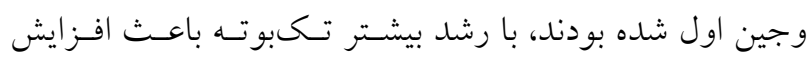

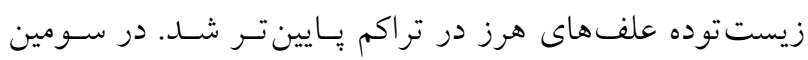

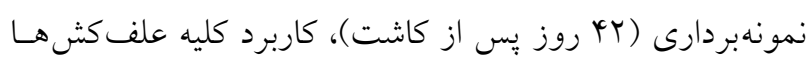

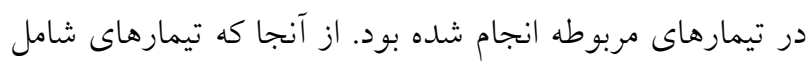

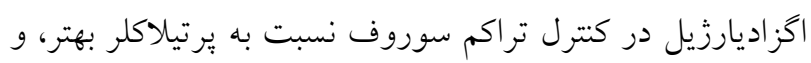

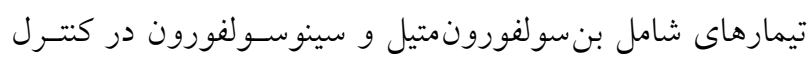

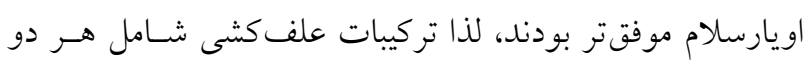

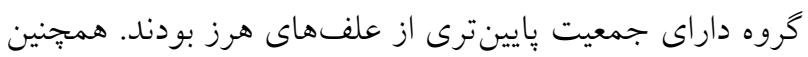

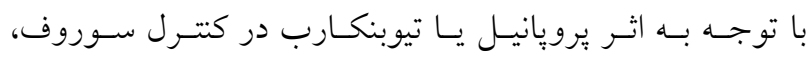

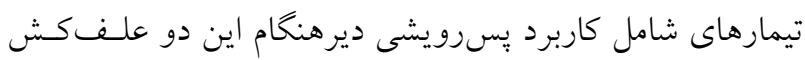

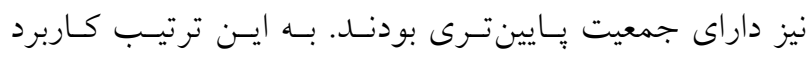

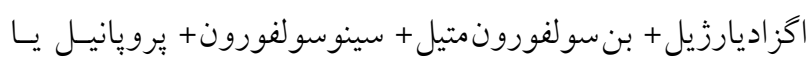

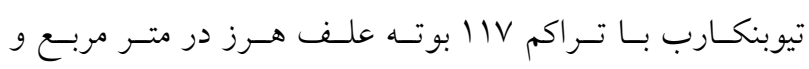

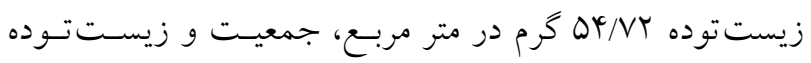


علفهاى هرز بودند. به ايـن ترتيـب بهتـرين نتيجـه در كـاربرد

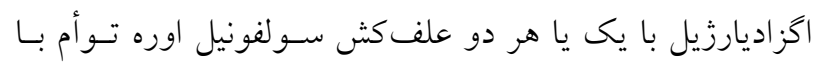

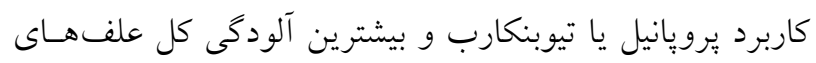

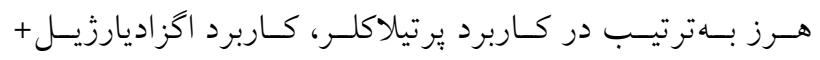

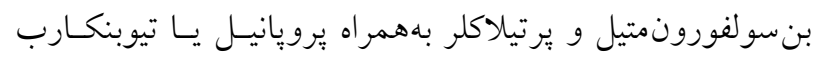
مشاهلده شد.

\section{اثر علف كشها بر رشد، عملكرد و اجزاى عملكرد برنج}

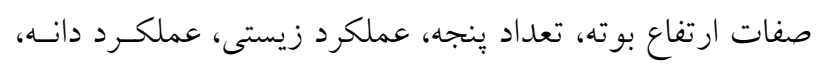

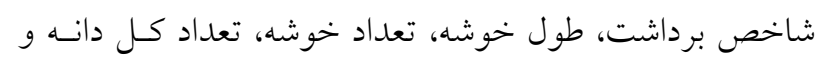

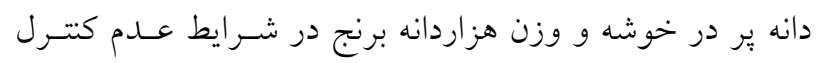

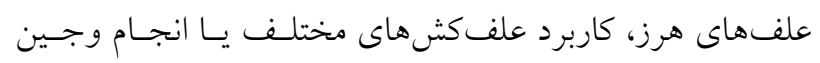

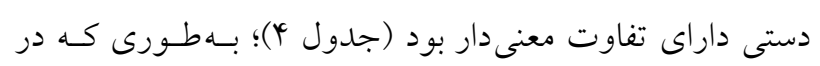

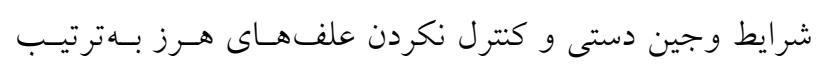

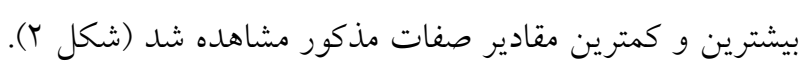

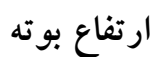

ارتفاع بوتهاى برنج در شرايط وجين دستى علـف آنهـاى هـرز

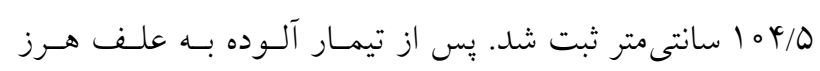

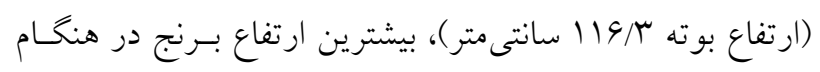

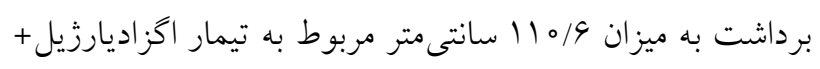

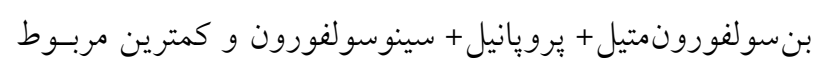

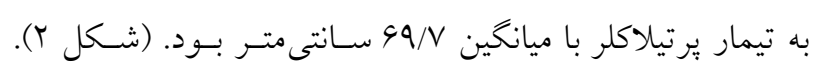

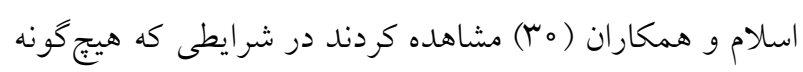

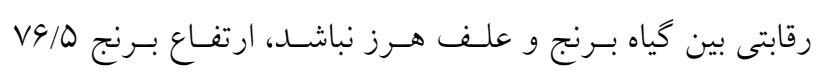

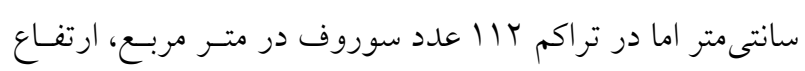

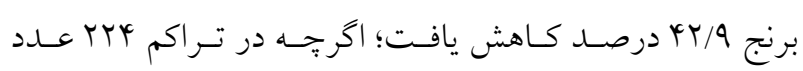

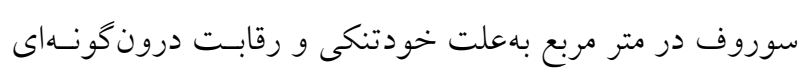
علف هرز، ارتفاع كياه بيشتر بوده است.

تعداد ينجه بيشترين و كمترين تعداد ينجه بهترتيب در تيمار وجين دستى و
نمونهبردارى به بعد در كـاهش زيسـتتـوده سـوروف بـهـطـور

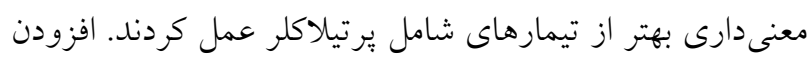

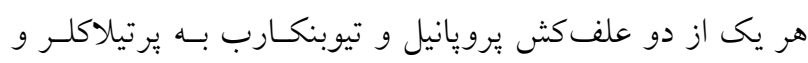

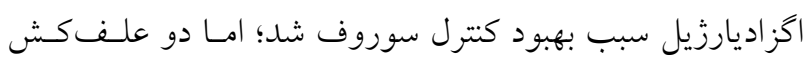

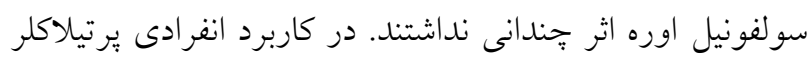

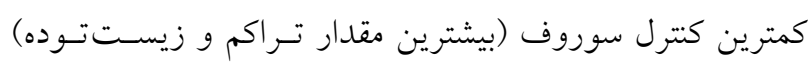

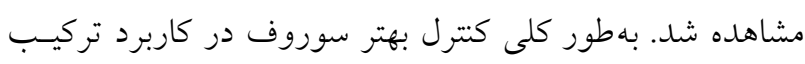

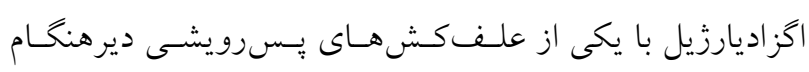

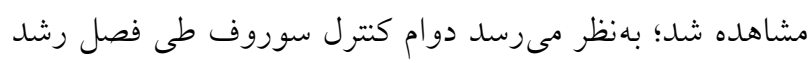

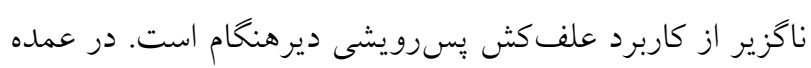

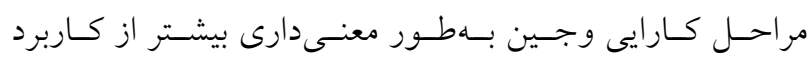
علف كش ها بود. با توجه به اثر مطلوب علف كش بن سولفودورونمتيل در كنترل

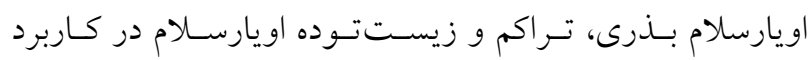

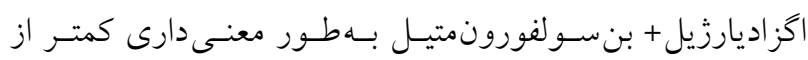

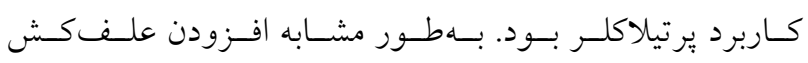

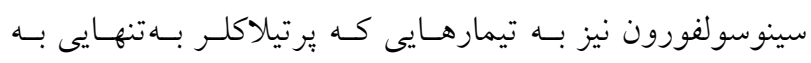

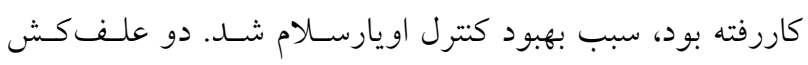

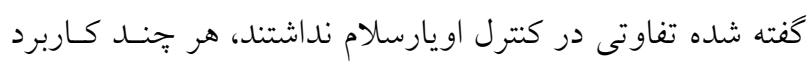

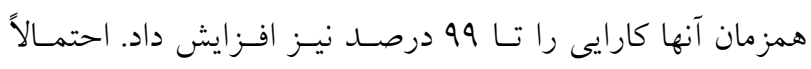

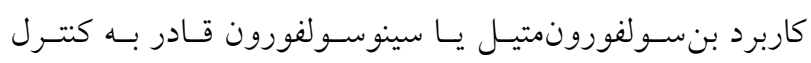

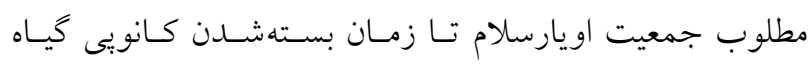

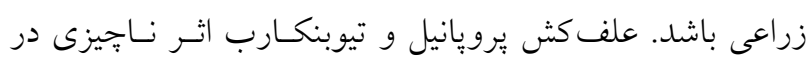

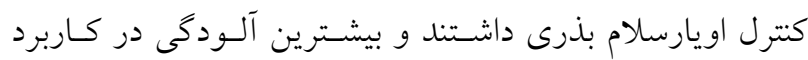

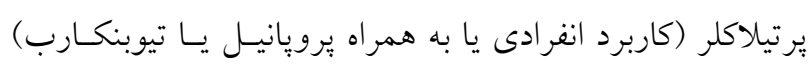

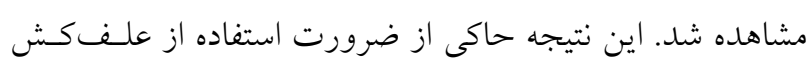

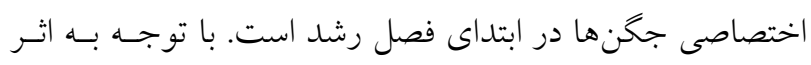

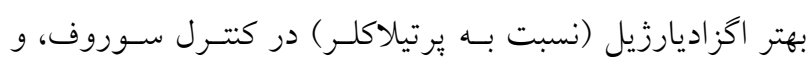

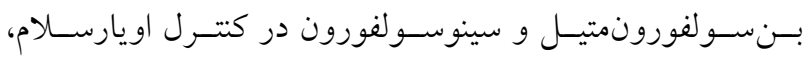

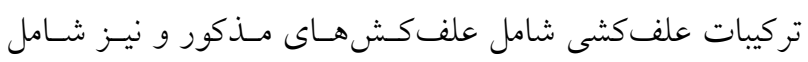
كاربرد بِ بسرويشى ديرهنكام يرويانيل يا تيوبنكارب (بهخاطر اثر

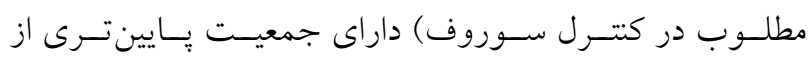




\begin{tabular}{|c|c|c|c|c|c|c|}
\hline شاخص برداشت & عملكرد دانه & عملكرد زيستى & ينجه & ارتفاع & درجه آزادى & منابع تغيير \\
\hline $1 / Y y^{\mathrm{ns}}$ & $1 \circ \Lambda V / \circ q^{n s}$ & $r \circ|V| / 9_{0}$ ns & $\left.|r G /|\right|^{n s}$ & $\circ / \wedge Y^{n s}$ & r & تكرار \\
\hline$\varphi \circ / \mathbb{F}^{* * *}$ & $r V \circ Y \circ Y I / N q^{* *}$ & 19RNYOHY/OO** & IIFT/YR** & $949 / \mathrm{q}^{* *}$ & 11 & علف كث \\
\hline$\Gamma / \wedge \Delta$ & IYTY/TY & $\mid F Y \wedge D / \Delta \circ$ & $9 \mathrm{~V} / \mathrm{IV}$ & $\circ / \mathrm{VA}$ & rt & خطا \\
\hline $0 / 1 \mu$ & $\varphi / \circ \wedge$ & $Y / \wedge \varphi$ & VNT & $\circ / 90$ & - & ضريب تغييرات (درصد) \\
\hline وزن هزاردانه & تعداد دانه يِ & تعداد دانه & تعداد خوشه & طول خوشه & درجه آزادى & منابع تغيير \\
\hline$\circ / \mu^{\mathrm{ns}}$ & $\circ / \circ \Delta^{\mathrm{ns}}$ & $\circ / \circ V^{n s}$ & $T / Y \varphi^{\mathrm{ns}}$ & $r / 99^{*}$ & r & 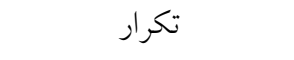 \\
\hline$Q / \circ \Gamma^{* *}$ & 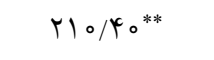 & $r \Delta \Delta / 4 q^{* *}$ & $1090 Y / 4 D^{* *}$ & $T V / V 0^{* *}$ & 11 & علف كش \\
\hline $0 / 09$ & $\circ / \Gamma \wedge$ & $0 / Y_{1}$ & $\Delta r / 01$ & $0 / 94$ & rt & خطا \\
\hline $1 / \pi_{0}$ & $1 / 9 \pi$ & $1 / \pi 1$ & $N / T$ & $T / 90$ & - & ضريب تغييرات (درصد) \\
\hline
\end{tabular}

الف

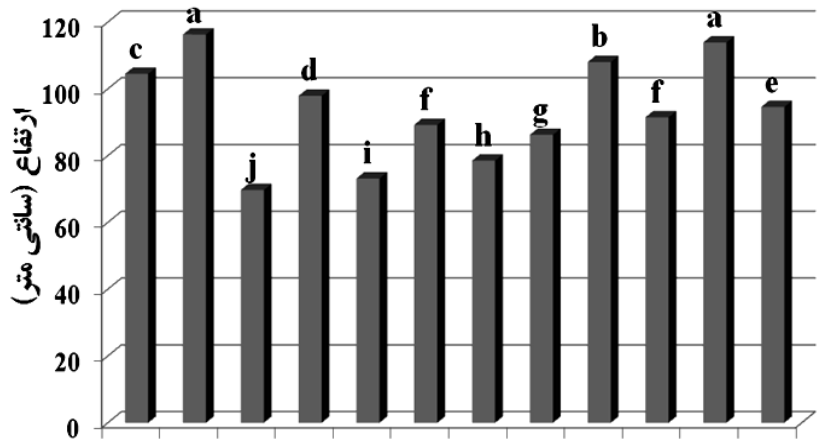

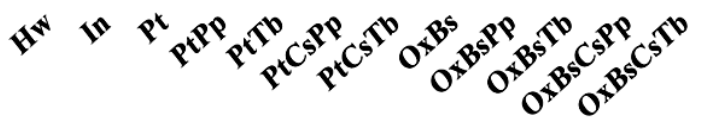

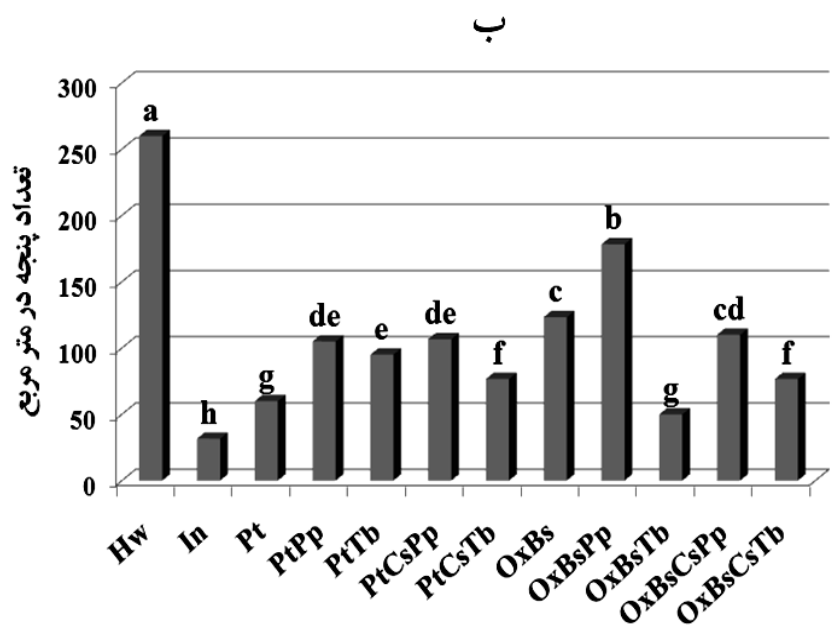

شكل r. اثر علفكشهاى مختلف بر: الف) ارتفاع، ب) تعداد ينجه، ج) عملكرد بيولوزيك، د) عملكرد دانه و ه) شاخص برداشت برنج در

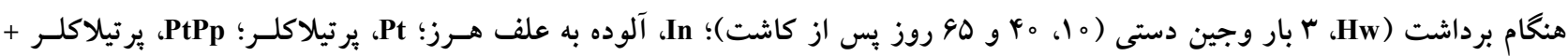

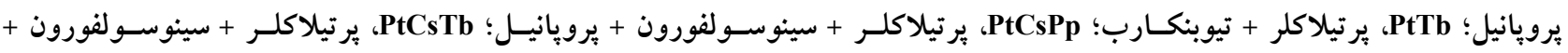

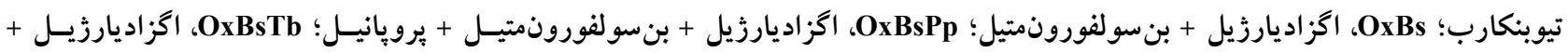
بن سولفورونمتيل + تيوبنكارب؛ OxBsCsPp، اگزاديارزيل + بنسولفورونمتيل + سينوسولفورون + برويانيل؛ OxBsCsTb، اخزاديارزيسل +

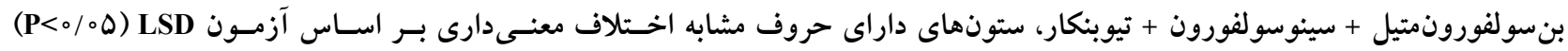


ج

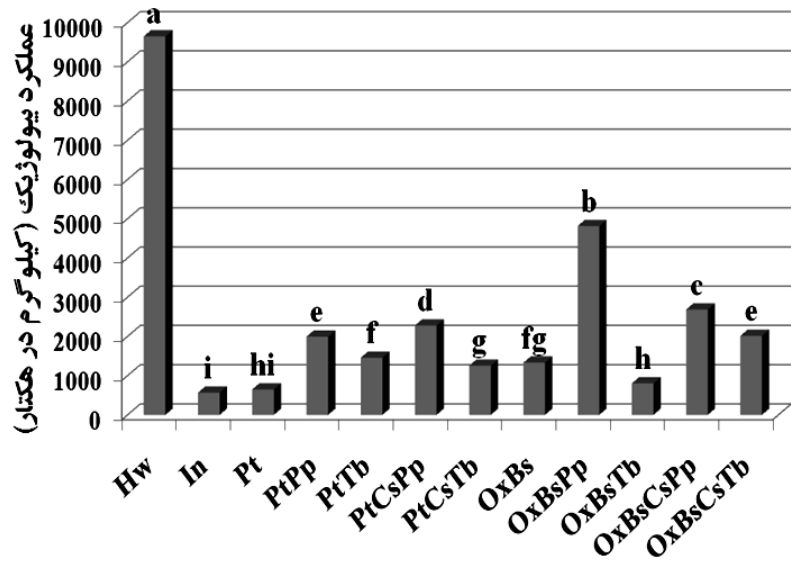

$\checkmark$

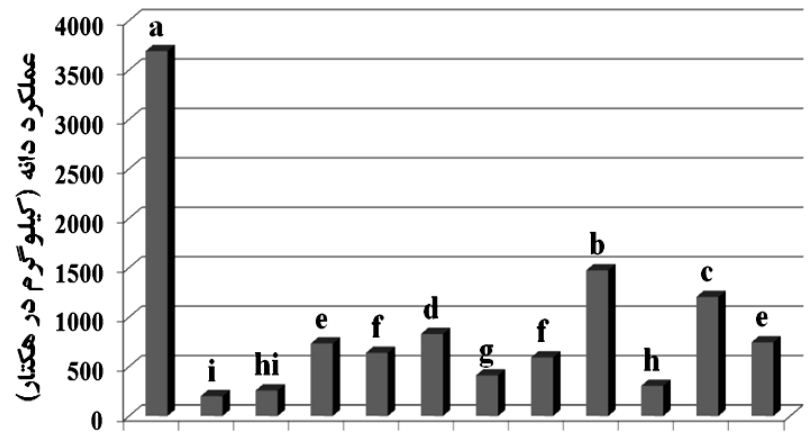

स゙ * *

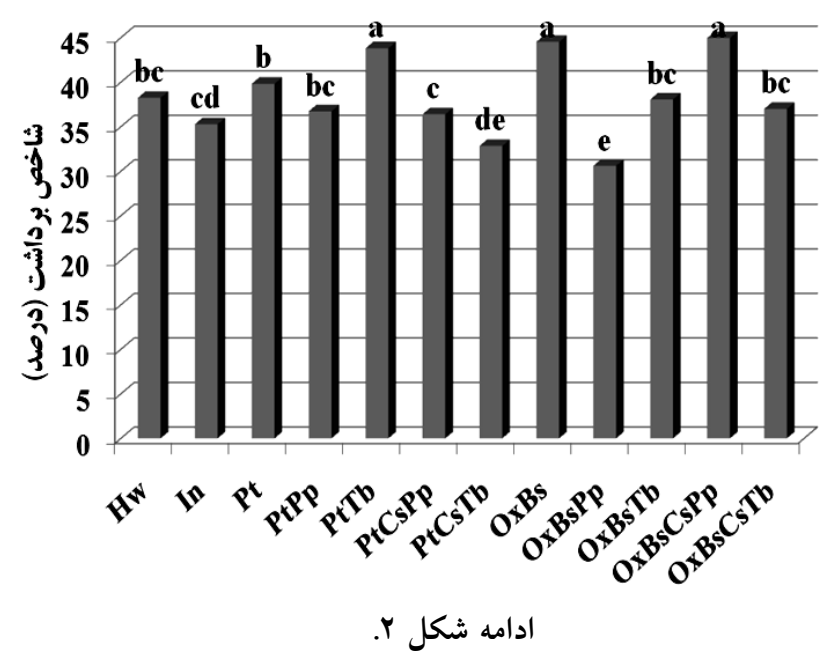

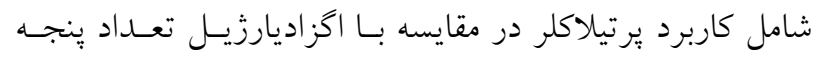

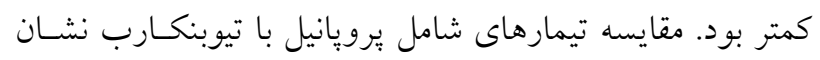

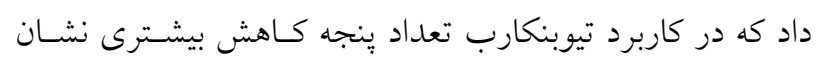

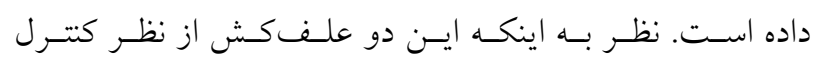

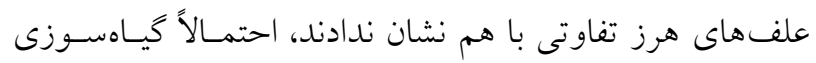

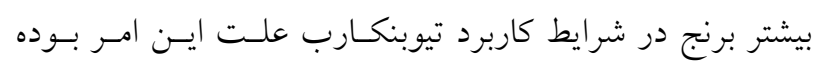

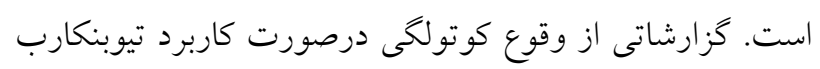
در شرايط كم آبى وجود دارد (ه9)

عملكرد بيولوزيك، عملكرد دانه و شاخص برداشت

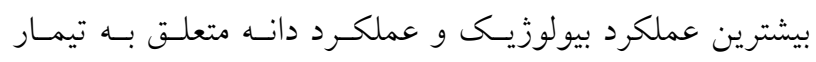

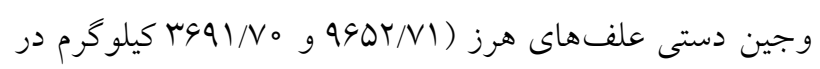

آلودخى علـف هـاى هـرز مشـاهده شــــ در تيمارهـاى كـاربرد

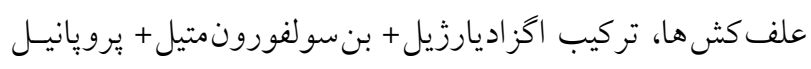
داراى بيشترين تعداد ينجه (VN إينجه در متسر مربـع) و كـاربرد

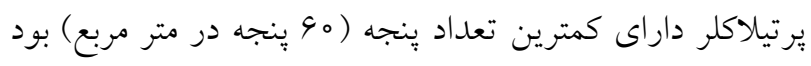
(شكل Y). در كشت نشايى تداخل تمام فصل سوروف با تـراكم

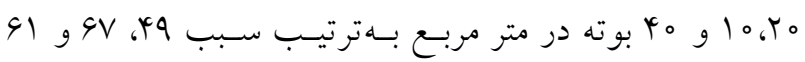

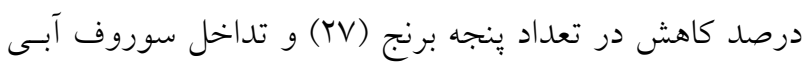

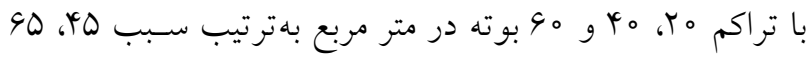

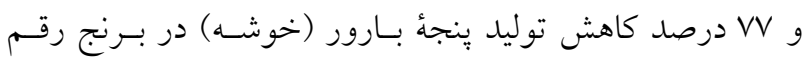

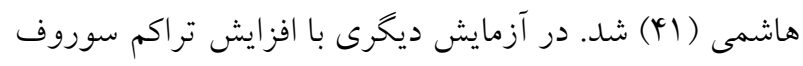

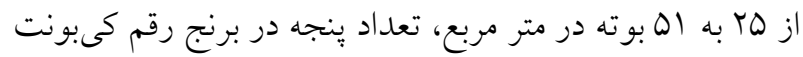

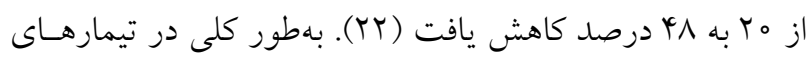


عملكرد دانه بين دو سيستم كشت مستقيم و نشايى وجـود نــارد (OY) و حتى در برخى مواقع ممكن است عملكرد دانه در كشت

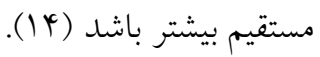

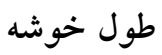

بيشترين طول خوشه مربوط به تيمار وجـين دسـتى علـفهـاى

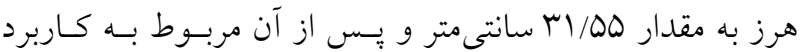

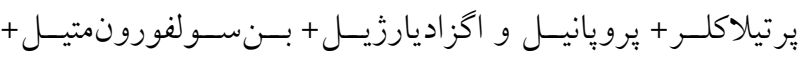

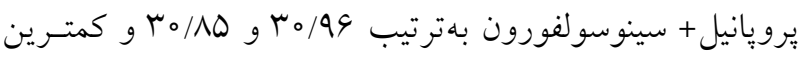

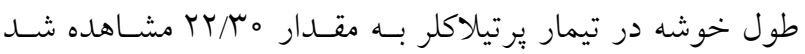

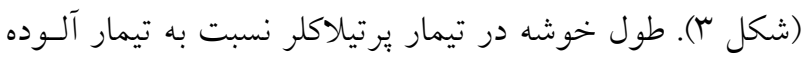

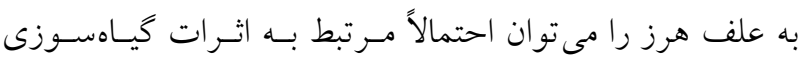
كاربرد علف كش روى گياه زراعى دانست.

\section{تعداد خوشه} بيشترين مقدار در وجين دستى علف هاى هرز ( (Tr خوشـه در

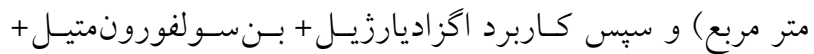

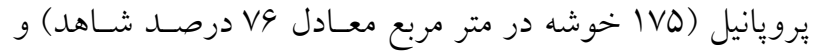
كمترين مقدار در شرايط آلوده به علـف هـرز (1 درصـــ تيمـار

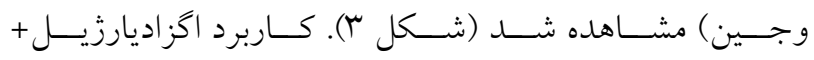
بن سولفورونمتيل + تيوبنكارب با داشتن تعـداد ينجـه، عملكــد

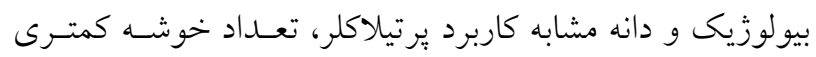

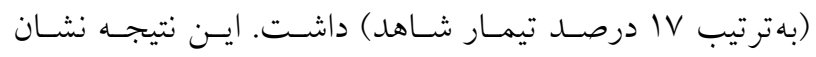

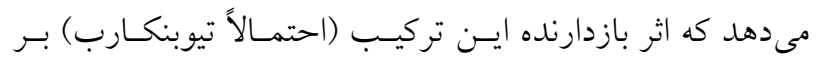

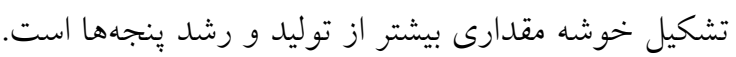

تعداد كل دانه و دانه ير در خوشه و وزن هزاردانه بيشترين تعداد كل دانه و دانه يــر در خوشـهـ مربـوط بـهـ تيمـار

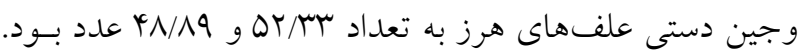
كمترين تعداد كل دانه و تعداد دانه ير در خوشه مربوط به تيمار

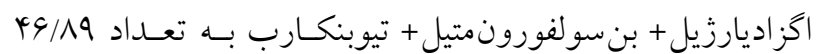

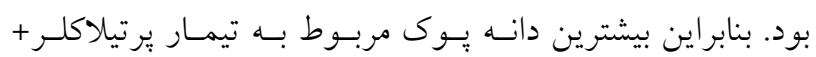

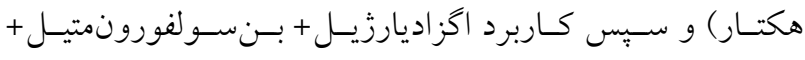

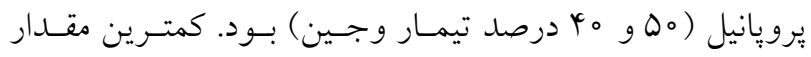

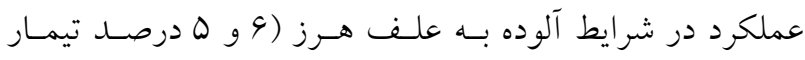
وجين) و كـاربرد انفــادى يرتيلاكلــ (هـر دو V درصــ تيمـار وجين) مشاهده شد. تيمار اخيـر تفـاوت معنسىدارى بـا كـاربرد اخزاديارزيل + بنسولفورونمتيل+ تيوبنكارب (هـر دو م درصـد

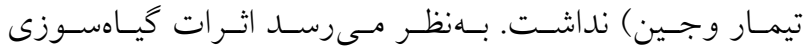

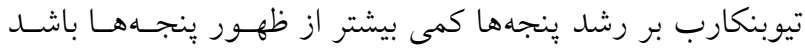

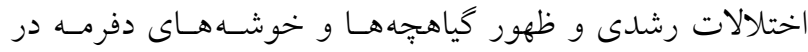
برنج رقم هاشمى در اثر تيمار با علف كش تيوبنكـارب كَزارش

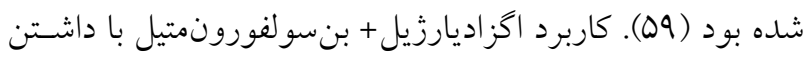
تعلداد يُجهاى معادل QV درصـد شـاهد وجسين، داراى عملكــرد

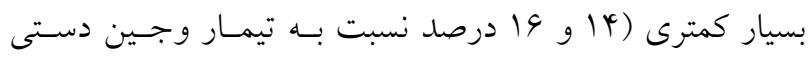
علفهاى هرز بهترتيب براى عملكـــد بيولوزيـك و دانـه) بـود.

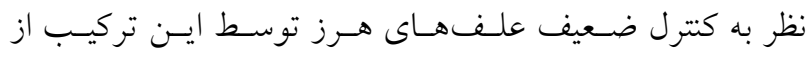

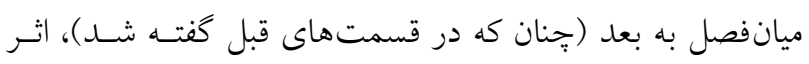
رقابت علفهاى هرز بر رشد ينجهها و توليد زيست توده و دانه بيشـتر بـوده اسـت. شـاخص برداشـت رونسـد مشخصسى بـين تيمارهاى آزمايشى نشان نداد و بيشـترين مقــدار آن در كـاربرد اخز اديارزيل + بن سـولفورونمتيـل + سينوسـو لفورون+ يرويانيـل،

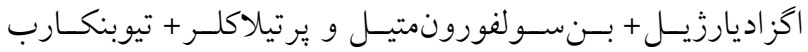

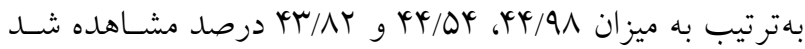

دركشت مستقيم بهدليل ظهـور همزمـان و يـا حتسى زودتـر

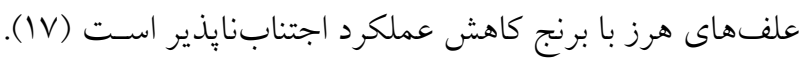

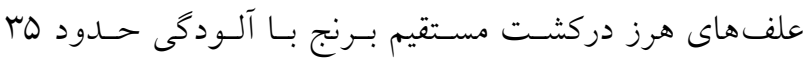

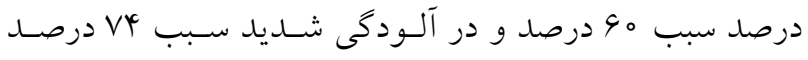

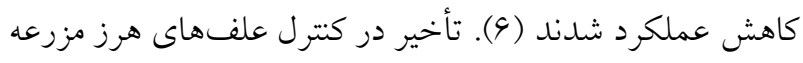

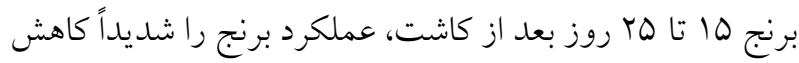
داد؛ جنانكه كاهش عملكرد برنج بهدليل رقابـت علـف هـرز در

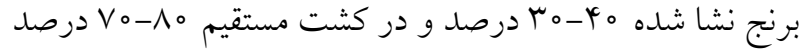
بود (9). درصورت كتترل علفهاى هرز اختلاف معنى دارى در 

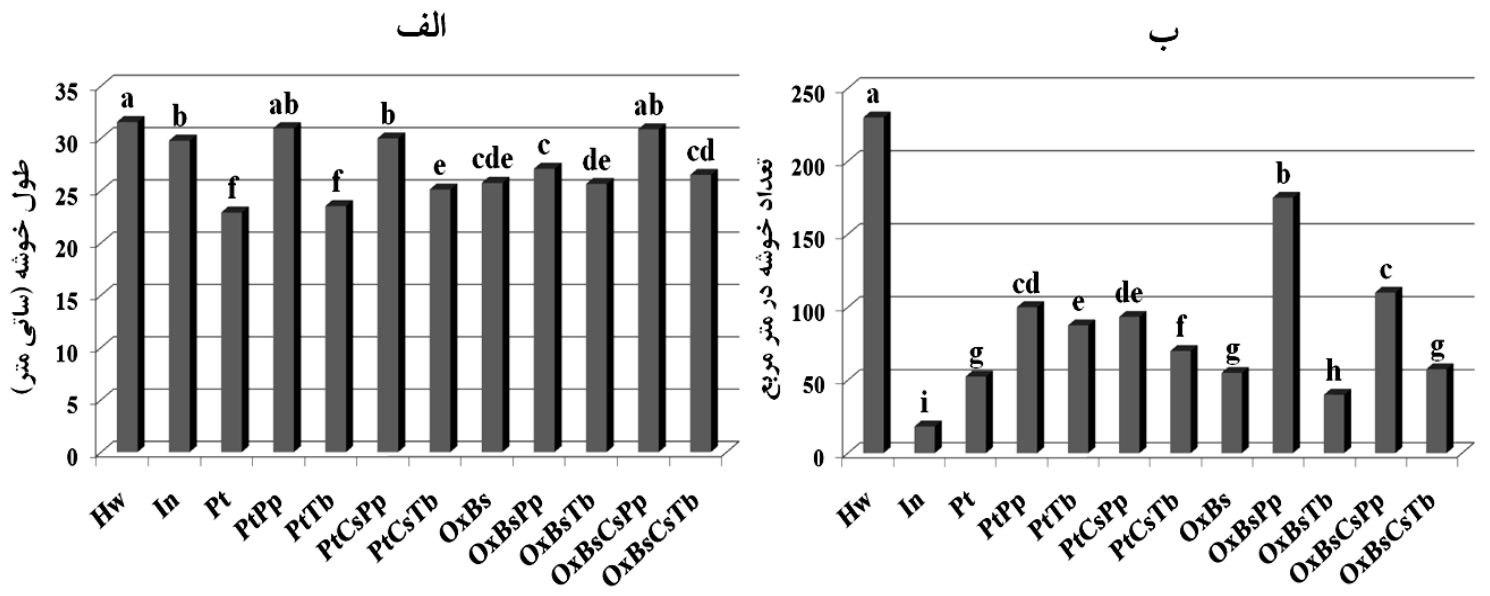

ج

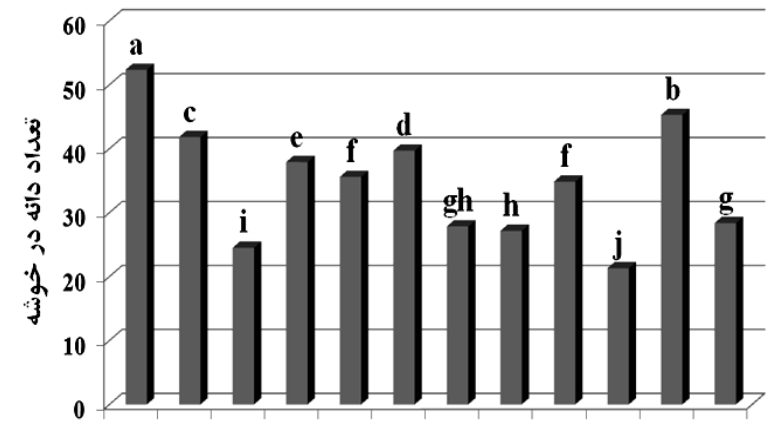

स゙ "
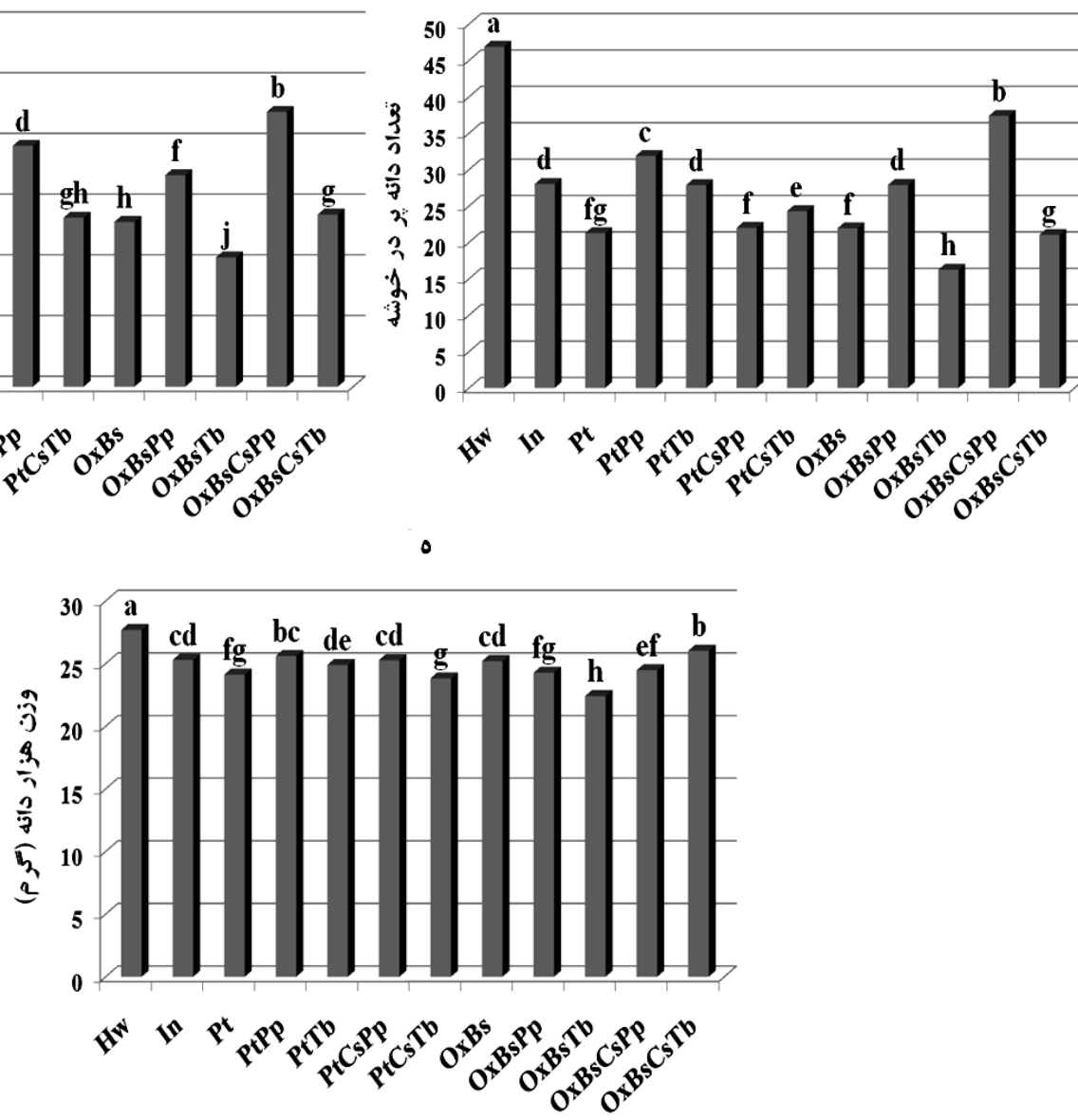

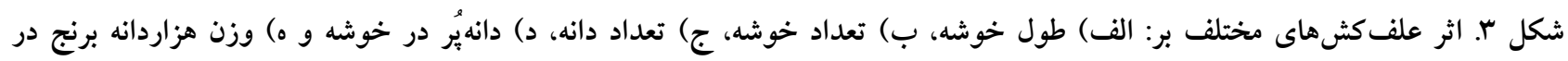

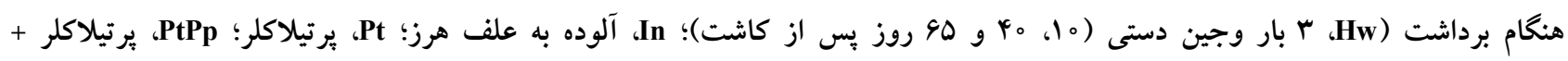

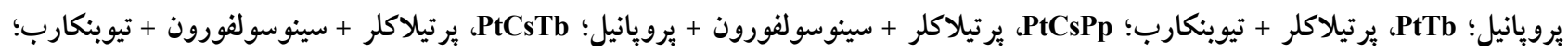

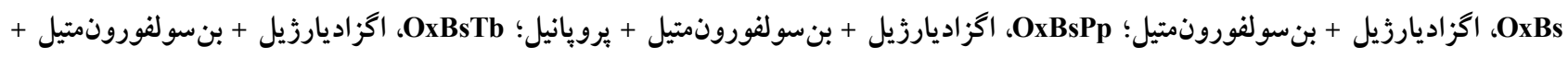

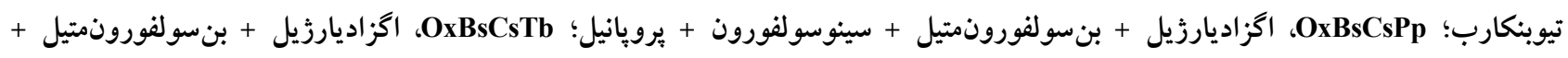

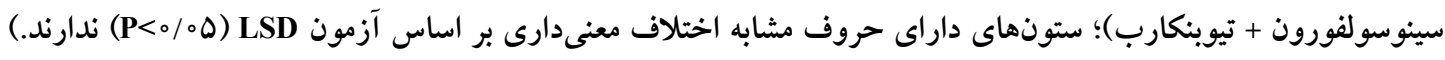


برداشت، طول خوشه، تعداد خوشه در واحد سطح، تعسداد كـل دانه و دانه ير در خوشه و وزن هزاردانه، همواره بيشترين مقدار

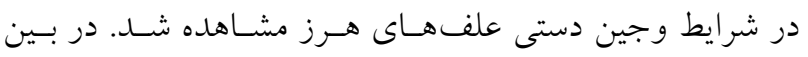
تيمارهاى كاربرد علف كش، با توجه به بيشـترين ميـزان رقابـت

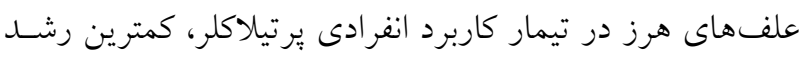

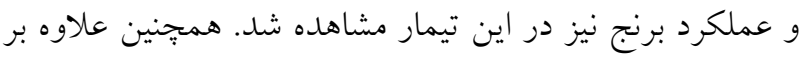

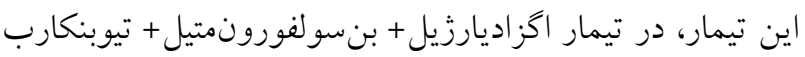

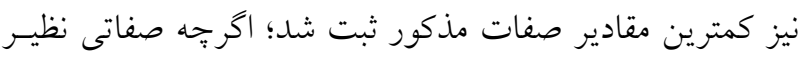

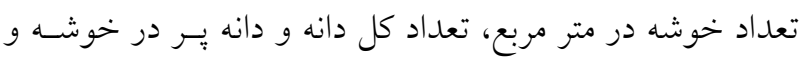

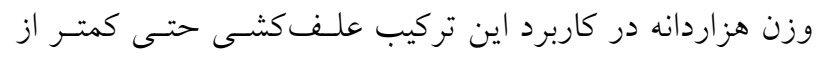

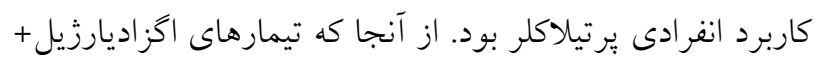

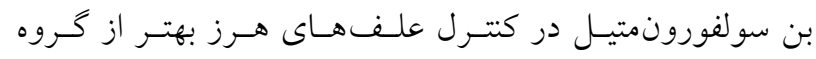

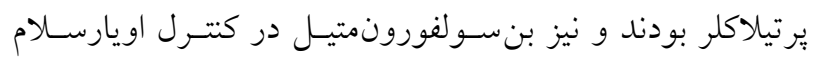
عملكرد خوبى داشت و علف كش يسرويشى تيوبنكارب سـبب تيب

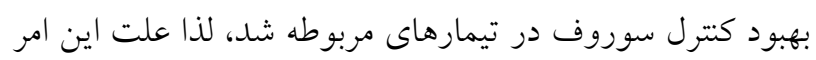

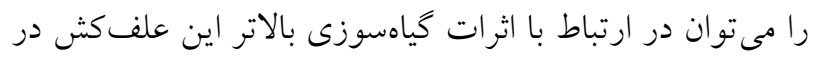

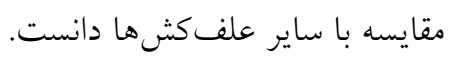

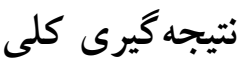

كليد موفقيت كشت مستقيم بـرنج فراهمسى تكنيكىهـاى مـؤثر

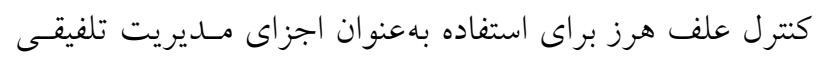

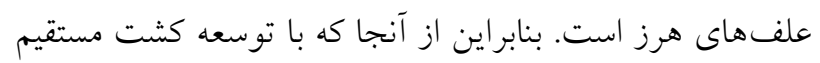

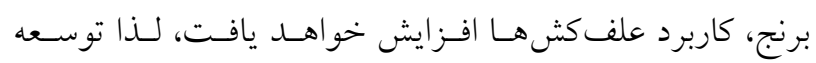

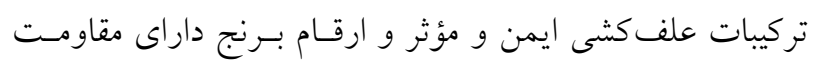

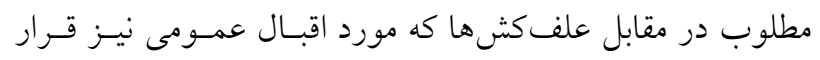

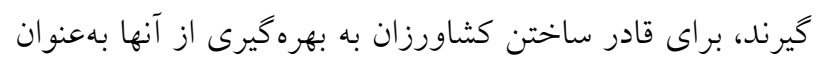
اجزاى مديريت تلفيقى علفهاى هرز مورد نيـاز خواهنــ بـود. نوع علفكش، روش و زمان كاربرد، نوع علف هرز، تحمل كياه

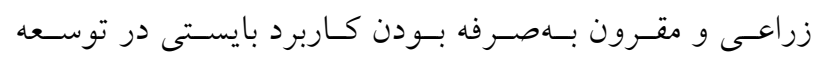

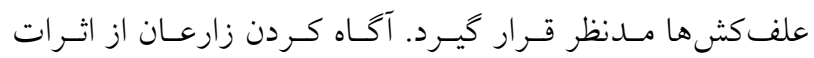

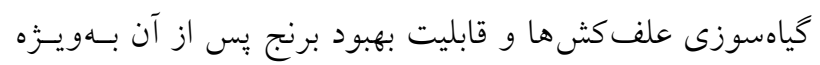

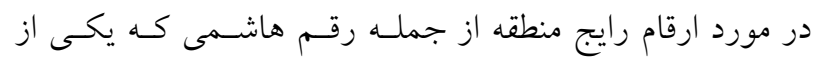

تيوبنكارب+ سينوسولفورون و تيمار رقابت كامل بـهـترتيـب بـــ

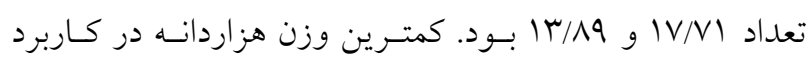

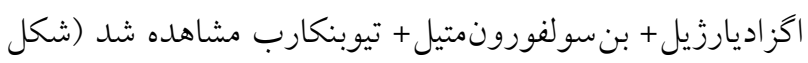

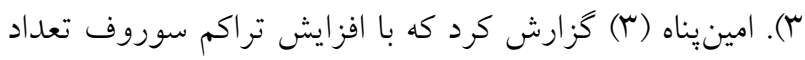

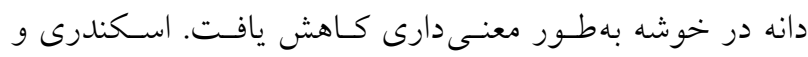

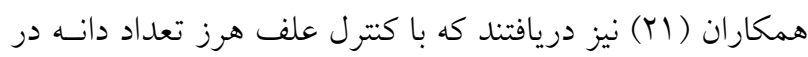
خوشه افزايش مى يابد. بررسى اجزاى عملكرد برنج نيز مشابه صـفات رويشى آن آن،

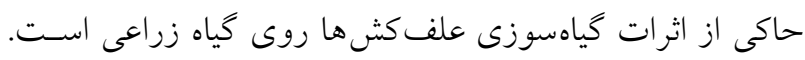

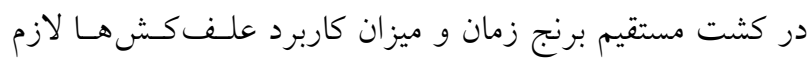

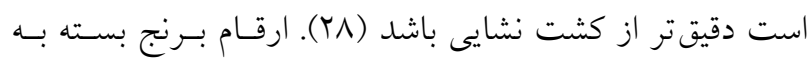

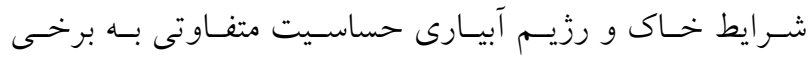

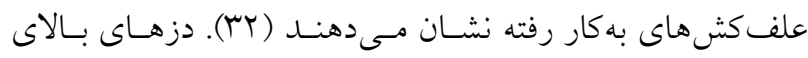

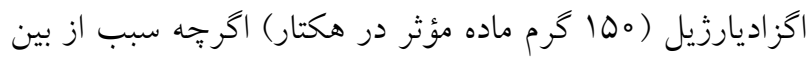

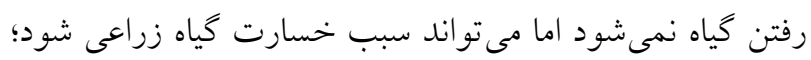

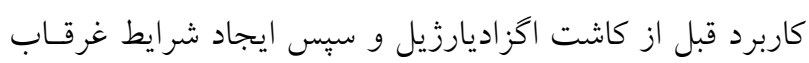

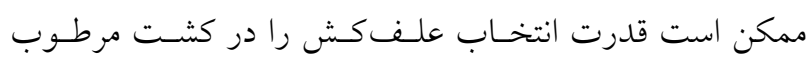

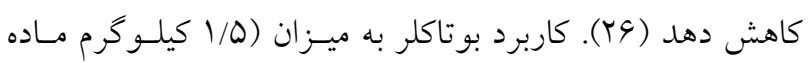

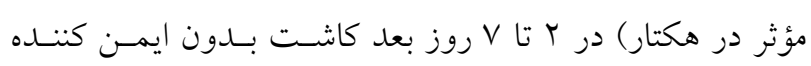

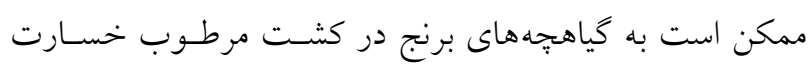
وارد آورد و كياهسوزى در كاربرد ديرتر افزايش يابد (†). بهطور

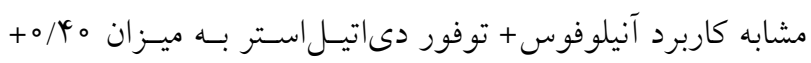

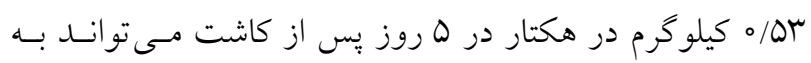

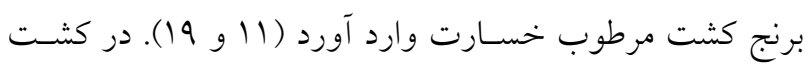

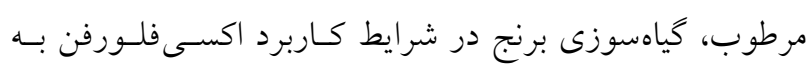

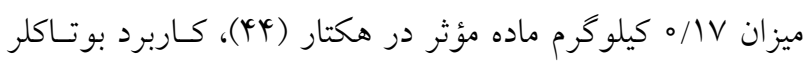
به ميزان 1، إه و Y كيلو گرم ماده مؤثر در هكتار (Y)، و كـاربرد

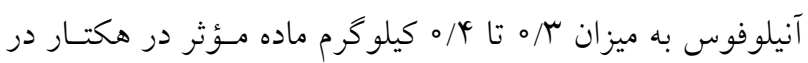

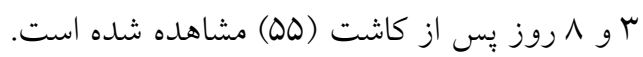

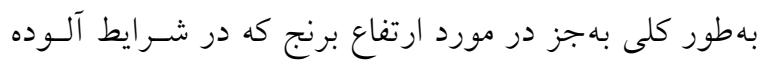

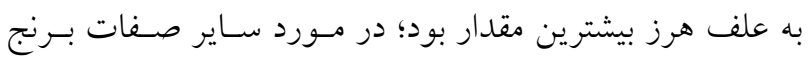

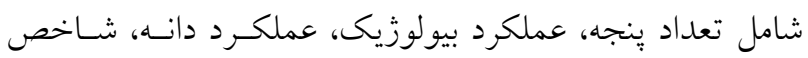




$$
\begin{aligned}
& \text { از اينكه علف كشها ابزارى مؤثر و با ارزش براى كشـاورزان در } \\
& \text { يرمصرف ترين ارقام بومى بهشـمار مسىرود، در يـذيرش كشـت } \\
& \text { كشت مستقيم در آينده باقى خواهند ماند، وجـود دارد. در ايسن } \\
& \text { مستقيم برنج حـائز اهميـت زيـادى اسـت. از آنجـا كـه كـاربرد } \\
& \text { راستا رويكرد كاهش مصرف علف كـش هـا كـه ضـمن كـاهش } \\
& \text { علف كشها در كشت مستقيم برنج هنخامى صورت مى گيرد كـهـ } \\
& \text { يتانسيل وقوع كياهسوزى، سـبب كـاهش ورود علـف كـش بـه }
\end{aligned}
$$

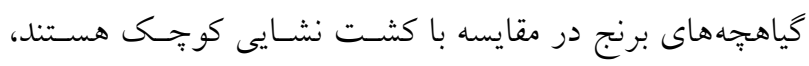

$$
\begin{aligned}
& \text { محيط مىشود، و نيز كاربرد بهينه علف كشهاى بيشرويشى و } \\
& \text { خطر كَياهسوزى ناشى از كاربرد علف كش زيـاد بـوده و تعيـين }
\end{aligned}
$$

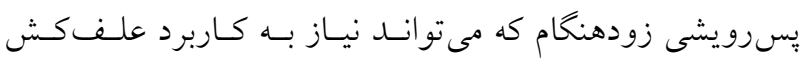

$$
\begin{aligned}
& \text { زمان بهينه كاربرد علف كش ها از اهميت زيادى برخوردار است. } \\
& \text { بنابراين با توجه به افزايش احتمال گياهسوزى در كشت مسـتقيم } \\
& \text { مرطوب، نياز مبرمى به بهينهسازى كاربرد علف كش ها و اطمينان }
\end{aligned}
$$

\section{منابع مورد استفاده}

1. Akbar, N., K. Jabran and M. A. Ali. 2011. Weed management improves yield and quality of direct seeded rice. Australian Journal of Crop Science 5(6): 688-694.

2. Alberto, A. M., L. H. Ziska, C. R. Cervancia and P. A. Manalo. 1996. The influence of increasing carbon dioxide and temperature on competitive interactions between a $\mathrm{C} 3$ crop, rice (Oryza sativa) and a $\mathrm{C} 4$ weed (Echinochloa glabrescens). Functional Plant Biology 23: 795-802.

3. Aminpanah, H. 2011. Response of more and less competitive rice cultivars to different densities of barnyardgrass. Electronic Journal of Crop Production 4(4): 67-84. (In Farsi).

4. Angiras, N. N. and S. S. Rana. 1998. Butachlor safener combinations for weed control in direct-seeded puddled rice. International Rice Research Notes 23(2): 46.

5. Asghari, J. 2002. The critical period of weed control in two (Improved and local) cultivars of rice (Oryza sativa L.) in drought stress conditions. Iranian Journal of Agricultural Sciences 33(4): 637-649. (In Farsi)

6. Azmi, M. and M. Z. Abdullah. 1998. Manual for the Identification and Control of Padi Angin (Weedy Rice) in Malaysia. Malaysian Agricultural Research and Development Institute.

7. Azmi, M., D. Chin, P. Vongsaroj and D. Johnson. 2005. Emerging issues in weed management of direct-seeded rice in Malaysia, Vietnam, and Thailand. PP. 196-198. In: Toriyama, K., K. L. Heong and B. Hardyb (Eds), Rice is Life: Scientific Perspectives for the 21st Century. Proceedings of the World Rice Research Conference, November, 2004.

8. Balasubramanian, V. and J. Hill. 2002. Direct seeding of rice in Asia: emerging issues and strategic research needs for the 21st century. In: Direct seeding: Research strategies and opportunities. PP. 15-39. In: Pandey, S., M. Mortimer, L. Wade, T. P. Tuong, K. Lopez and B. Hardy (Eds). The International Rice Research Institute (IRRI).

9. Balasubramaniyam, P. and P. Palaniappans. 2004. Principles and Practices of Agronomy. 2nd edition. Agrobios, Jodhpur.

10. Begum M., S. A. Jurami, R. Amartalingam, A. BinMan and S. O. B. S. Rastans. 2006. The effects of sowing depth and flooding on the emergence, survival, and growth of Fimbristylis miliacea (L.) Vahl. Weed Biology and Management 6: 157-164.

11. Behera, A. K. and S. N. Jena. 1997. Weed management in direct seeded rice under puddled condition. Oryza 34(4): 337-340.

12. Bernasor, P. and S. De Datta. 1988. Long-term effects of tillage, cultivar and herbicide on weed shift and control in broadcast-seeded flooded rice. Soil and Tillage Research 12: 197-212.

13. Bhuiyan, S., M. Sattar and M. Khan. 1995. Improving water use efficiency in rice irrigation through wet-seeding. Irrigation Science 16: 1-8.

14. Bhushan, L., J. K. Ladha, R. K. Gupta, S. Singh, A. Tirol-Padre, Y. Saharawat, M. Gathala and H. Pathak. 2007. Saving of water and labor in a rice-wheat system with no-tillage and direct seeding technologies. Agronomy Journal 99: $1288-1296$.

15. Chauhan, B. S. 2012. Weed ecology and weed management strategies for dry-seeded rice in Asia. Weed Technology 26: 1-13.

16. Chauhan, B. and D. Johnson. 2009. Ecological studies on Cyperus difformis, Cyperus iria and Fimbristylis miliacea: three troublesome annual sedge weeds of rice. Annals of Applied Biology 155: 103-112.

17. Chauhan, B. S. and D. E. Johnson. 2010. Implications of narrow crop row spacing and delayed Echinochloa colona 
and Echinochloa crus-galli emergence for weed growth and crop yield loss in aerobic rice. Field Crops Research 117: $177-182$.

18. Chin D. V. 2001. Biology and management of barnyardgrass, red sprangletop and weedy rice. Weed Biology and Management 1: 37-41.

19. Choudhary, J. K. and R. K. Thakuria. 1998. Evaluation of herbicides in wet-seeded, late Sali (winter) rice (Oryza sativa) in Assam. Indian Journal of Agronomy 43: 291-294.

20. De Datta, S. K., P. C. Bernasor, T. R. Migo, M. A. Llagas and P. Nantasomsaran. 1989. Emerging Weed Control Technology for Broadcast Seeded rice. In: Progress in Irrigated Rice Research. Manilla (Philippines). International Rice research Institute.

21. Eskandari-Cherati, F., H. Bahrami and A. Asakereh. 2011. Evaluation of traditional, mechanical and chemical weed control methods in rice field. Australian Jounal of Crop Science 5(8): 1007-1013.

22. Estorninos Jr, L. E., D. R. Gealy, E. E. Gbur, R. E. Talbert and M. R. McClelland. 2005. Rice and red rice interference. II. Rice response to population densities of three red rice (Oryza sativa) ecotypes. Weed Science 53: 683-689.

23. Farooq, M., K. H. Siddique, H. Rehman, T. Aziz, D. J. Lee and A. Wahid. 2011. Rice direct seeding: experiences, challenges and opportunities. Soil and Tillage Research 111: 87-98.

24. Ferrero, A. and N. Nguyen. 2004. Constraints and opportunities for the sustainable development of rice-based production systems in Europe. In FAO Rice Conference.

25. Gibson, K. D., A. J. Fischer, T. C. Foin and J. E. Hill. 2003. Crop traits related to weed suppression in water-seeded rice (Oryza sativa L.). Weed Science 51: 87-93.

26. Gitsopoulos, T. and R. Froud-Williams. 2004. Effects of oxadiargyl on direct-seeded rice and Echinochloa crus-galli under aerobic and anaerobic conditions. Weed research 44: 329-334.

27. Golmohammadi M. J., H. Alizadeh, B. Yaghoubi and M. Nahvi. 2010. Evaluation of competition of early watergrass (Echinochloa oryzicola (Ard) Fisher) on rice fields of Guilan. Journal of Agroecology. 2: 95-102. (In Farsi).

28. Haefele, S., D. Johnson, D. M'Bodj, M. Wopereis and K. Miezan. 2004. Field screening of diverse rice genotypes for weed competitiveness in irrigated lowland ecosystems. Field Crops Research 88: 39-56.

29. Hassan, S. M., A. N. Rao, A. O. Bastawisi and I. R. Aidy. 1995. Weed management in wet seeded rice in Egypt. In: Constraints, opportunities and innovations for wet-seeded rice. Moody, K., (Eds). IRRI Discussion Paper Series, no. 10. International Rica Research Institute, (Philippines).

30. Islam, M. F., S. R. Karim, S. Haque and M. S. Islam. 2003. Effect of population density of Echinochloa crusgalli and Echinochloa colonum on rice. Journal of Agronomy 2: 120-125.

31. JeKyu, K., K. SangSoo, P. SungTae, K. YangSoon, K. SoonChul, L. MoonHee, S. Peng and B. Hardy. 2001. WetSeeded Rice Cultivation Technology in Korea. In: Rice Research for Food Security and Poverty Alleviation. Proceedings of the International Rice Research Conference, Los Baños, Philippines, March- April (2000). International Rice Research Institute (IRRI).

32. Jordan, D. L., D. E. Sanders, S. D. Linscombe and B. J. Williams. 1998. Response of four rice (Oryza sativa) cultivars to triclopyr. Weed Technology 12: 254-257.

33. Kaur, J. and A. Singh. 2017. Direct seeded rice: prospects, problems/ constraints and researchable issues in India. Current Agriculture Research Journal 5: 13-32.

34. Khaliq, A. and A. Matloob. 2011. Weed crop competition period in three fine rice cultivars under direct seeded rice culture. Pakistan Journal of Weed Science Research 17: 229-243.

35. Kumar, V. and J. K. Ladha. 2011. Direct seeding of rice: recent developments and future research needs. Advances in Agronomy 111: 297-413.

36. Liqin, G., C. Jiansheng, Z. Juyuan, L. Shanqing, Z. Jianguo, C. Lirong and Z. Yumin. 2004. Appraisal of herbicides for one-time weeding of direct seeding rice field. Acta Agriculture Shanghai 20: 91-94.

37. Liscano, J., B. Williams and T. Croughan. 1999. Barnyardgrass (Echinochloa crus-galli) control in dry-seeded imidazolinone tolerant rice. In: Proceedings of Southern Weed Science Society, USA. volume 52, p. 13.

38. Mahajan, G. and B. S. Chauhan. 2013. Herbicide options for weed control in dry-seeded aromatic rice in India. Weed Technology 27: 682-689.

39. Maity, S. K. and P. K. Mukerjee. 2008. Integrated weed management in dry-seeded rice (Oryza sativa). Indian Journal of Agronomy 53(2): 116-120.

40. Mohamad Sharifi, M. 2001. Weeds of Rice Field in Iran. Publication of Agricultural Research, Education and Extension Organization. (In Farsi).

41. Mohammadvand, E., A. Koocheki, M. Nassiri Mahallati and B. Yaghoubi. 2020. Effects of emergence time in nursery and density of watergrass (Echinochloa oryzoides (Ard.) Fritsch) on competitive ability with rice (Oryza sativa L.) (II. End season studies: yield and competitiveness). Journal of Agroecology 11: 1225-1239. 
42. Montazeri, M. and R. Pourazar. 2009. Comparison the efficacy of penoxulam 240 SC with the rice selective herbicides registerd in Iran. Weed Research Journal 1: 55-64. (In Farsi).

43. Moody, K. 1992. Efficient herbicide use in tropical crops. In: Proceedings of the 1st International Weed Control Congress. Melbourne, Australia.

44. Natarajan, S. and G. Kuppuswamy. 1997. Effect of application of butachlor and oxyfluorfen on direct sown rice on puddled soil. Oryza 34: 70-72.

45. Noorbakhshian, S. J. 2000. The yield comparision of rice varieties in direct seeding and transplanting method. Iranian Journal of Crop Science 2(4): 25-32. (In Farsi).

46. Pellerin, K. J. and E. P. Webster. 2004. Imazethapyr at different rates and timings in drill-and water-seeded imidazolinone-tolerant rice. Weed Technology 18: 223-227.

47. Rahman, M., A. Juraimi, J. Suria, B. Azmi and P. Anawar. 2012. Response of weed flora to different herbicides in aerobic rice system. Science Research and Essays 7(1): 12-23.

48. Rao, A., D. Johnson, B. Sivaprasad, J. Ladha and A. Mortimer. 2007. Weed management in direct-seeded rice. Advances in Agronomy 93: 153-255.

49. Rashed-Mohasel, M. and S. Mousavi. 2007. Principles of Weed Management. Ferdowsi University of Mashhad Publication, Iran. (In Farsi)

50. Rodenburg, J. and D. Johnson. 2009. Weed management in rice-based cropping systems in africa. Advances in Agronomy 103: 149-218.

51. Salehian, H., H. Rahimian, H. E. Majidi and A. Ghanbari. 2003. A Survey of natural weed population inerference in wheat crop in Mazandran province. Iranian Journal of Crop Science 5(3): 1-14. (In Farsi).

52. Sanusan, S., A. Polthanee, A. Audebert, S. Seripong and J. C. Mouret. 2010. Suppressing weeds in direct-seeded lowland rainfed rice: Effect of cutting dates and timing of fertilizer application. Crop Protection 29: 927-935.

53. Singh, S., L. Bhushan, J. Ladha, R. Gupta, A. Rao and B. Sivaprasad. 2006. Weed management in dry-seeded rice (Oryza sativa) cultivated in the furrow-irrigated raised-bed planting system. Crop Protection 25: 487-495.

54. Singh, S., J. K. Ladha, R. K. Gupta, L. Bhushan and A. N. Rao. 2008 Weed management in aerobic rice systems under varying establishment methods. Crop Protection 27: 660-671.

55. Sreedevi, B., S. P. Singh, S. V. Subbaiah and P. Krishnamurthy. 2001. Performance of herbicides in wetseeded rice. Oryza 38: 52-55.

56. Statistics of Agriculture. 2014. Available at: www.maj.ir.

57. Suria, A. J., A. S. Juraimi, M. Rahman, A. B. Man and A. Selamat. 2013. Efficacy and economics of different herbicides in aerobic rice system. African Journal of Biotechnology 10: 8007-8022.

58. Talbert, R., L. Schmidt, J. Rutledge, E. Scherder and F. Baldwin. 1999. Confirmation, population genetics, and control of propanil-resistant and -susceptible barnyardgrass. pp. 103-118. In: Wells, B. R., R. J. Norman and T. H. Johnston (Eds.). Fayetteville, AR Arkansas Agricultural Experiment Station, University of Arkansas Research Series.

59. Yaghoubi, B., M. A. Baghestani, H. Alizadeh, H. Rahimian, N. Davatgar and A. Farahpour. 2013. Study the effect of thiobencarb method of application on causing dwarfism in rice. Iranian Journal of Weed Science 8: 1-16. (In Farsi).

60. Zand, E., M. A. Baghestani, N. Nezamabadi, P. Shimi and S. K. Mousavi. 2017. A Guide to Chemical Control of Weeds in Iran, with the Approach of Shifting Flora, Fifth edition. Jihad of Mashhad University Press. (In Farsi). 


\title{
The Feasibility Study of Utilizing Common Herbicides of Transplanted Rice for Direct Wet-Seeding of Hashemi Cultivar
}

\author{
V. Alipoor-Stakhri ${ }^{1}$, J. Asghari ${ }^{*}$, S. M. R. Ehteshami ${ }^{3}$ and E. Mohammadvand ${ }^{4}$
}

(Received: November 12-2017; Accepted: December 24-2019)

\begin{abstract}
To investigate some common herbicides of transplanted rice for direct wet-seeding of Hashemi cultivar, this study was conducted in a randomized complete block design with three replications. Treatments were as follow: (i) recommended dose of pretilachlor, (ii) oxadiargyl + bensulfuron-methyl, (iii-vi) adding propanil or thiobencarb to treatment (i) and (ii), (vii-x) adding cinosulfuron to treatment (iii) to (vi), (xi) weed free condition, and (xii) weed infested condition. The highest total weed infestations were observed when pretilachlor, oxadiargyl + bensulfuron-methyl and pretilachlor plus propanil or thiobencarb had been applied. The highest rice height was recorded in weed infested, but for other traits, comparison of herbicide treatments showed the least rice growth and yield for pretilachlor (due to the highest weed competition) and oxadiargyl + bensulfuron-methyl + thiobencarb. In the recent treatment panicle and grain number, and 1000-grain weight were lower than those for individual application of pretilachlor. Since applying oxadiargyl + bensulfuron-methyl suppressed weeds better than treatments containing pretilachlor, and also considering the effective control of nutsedge by bensulfuron-methyl, and barnyardgrass by thiobencarb, it seems that the phytotoxicity effects of oxadiargyl + bensulfuron-methyl + thiobencarb on rice are serious. In the herbicide applied treatments, the maximum number of tiller and panicle, and biological and grain yield were observed in oxadiargyl + Bensulfuron-methyl + Propanile treatments. Despite the acceptable weed control, it seems that Hashemi cultivar was susceptible to herbicides in saturated soil condition and symptoms of phytotoxicity were appeared in crop plants.
\end{abstract}

Keywords: Pretilachlor, Oxadiargyl, Bensulfuron methyl, Propanil, Thiobencarb, Cinosulfuron

1, 2, 3, 4. MSc. Student, Professor and Assistant Professors, Respectively, Department of Agronomy and Plant Breeding, Faculty of Agricultural Sciences, University of Guilan, Rasht, Iran.

*: Corresponding Author, Email: asghari@guilan.ac.ir 